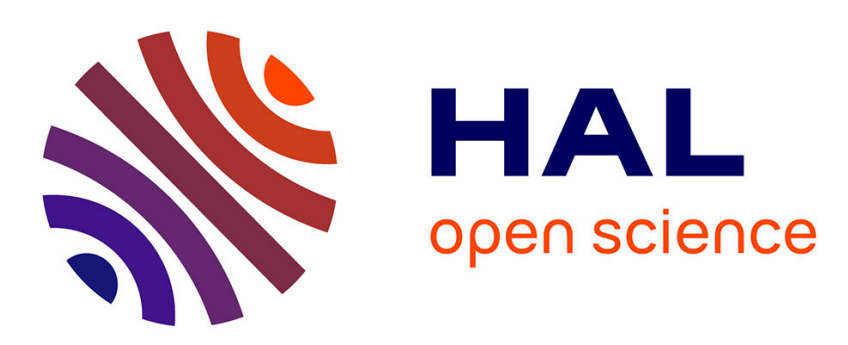

\title{
Molecular tectonics: tuning the dimensionality and topology of extended cyanocuprate networks using a bisamidinium cation
}

Sylvie Ferlay, Pierre Dechambenoit, Nathalie Kyritsakas, Mir Wais Hosseini

\section{- To cite this version:}

Sylvie Ferlay, Pierre Dechambenoit, Nathalie Kyritsakas, Mir Wais Hosseini. Molecular tectonics: tuning the dimensionality and topology of extended cyanocuprate networks using a bisamidinium cation. Dalton Transactions, 2013, 42, pp. 11661-11671. 10.1039/c3dt51252e . hal-01087251

\section{HAL Id: hal-01087251 \\ https://hal.science/hal-01087251}

Submitted on 2 Dec 2020

HAL is a multi-disciplinary open access archive for the deposit and dissemination of scientific research documents, whether they are published or not. The documents may come from teaching and research institutions in France or abroad, or from public or private research centers.
L'archive ouverte pluridisciplinaire HAL, est destinée au dépôt et à la diffusion de documents scientifiques de niveau recherche, publiés ou non, émanant des établissements d'enseignement et de recherche français ou étrangers, des laboratoires publics ou privés. 


\title{
Molecular tectonics: tuning dimensionality and topology of extended cyanocuprate networks by bisamidinium cation
}

\author{
Sylvie Ferlay, ${ }^{a^{*}}$ Pierre Dechambenoit ${ }^{\mathrm{a}, \mathrm{b}}$, Nathalie Kyritsakas ${ }^{\mathrm{a}}$ and Mir Wais Hosseini ${ }^{\mathrm{a}^{*}}$ \\ Received (in XXX, XXX) Xth XXXXXXXXX 20XX, Accepted Xth XXXXXXXXX 20XX \\ ${ }_{5}$ DOI: $10.1039 / \mathbf{b 0 0 0 0 0 0 x}$
}

Upon combining $\mathrm{KCu}(\mathrm{CN})_{2}$ with six different symmetrical dicationic bisamidinium moieties possessing different shapes and geometries, seven new coordination networks of the cyanocuprate type displaying 1-, 2- and 3-D dimensionality have been obtained. The formation of networks results from the interconnection of $\mathrm{Cu}(\mathrm{I})$ centres by cyanide anions through different bridging modes. The organic dicationic tectons interact with the anionic networks by charge-assisted H-bonds and, depending on their geometric features, they play different 10 structuring roles. In the case of the 1D cyanocuprate networks, the organic cation interconnects consecutive anionic chains increasing thus the overall dimensionality of the arrangement to 2D. For the 2D networks, either riveting or intercalation has been observed. For the riveting case, either the process takes place only between two consecutive sheets leading to a double layer type arrangement and thus without increase of dimensionality, or between consecutive 2D networks in an alternate fashion. In the latter case, the dimensionality of the overall architecture is increased to 3 as for the intercalated case. For the $3 \mathrm{D}$ architectures, the dicationic moieties are located within 15 the generated channels.

\section{Introduction}

The design and formation of extended coordination networks is a matter of current investigations. The interest in this type of 20 solid-state materials arises from their possible applications in sensing, gas storage and/or separation, catalysis, drug delivery etc. Since two decades, many examples of coordination networks, ${ }^{1}$ in particular of the $\mathrm{MOFs}^{2}$ type have been described over the last two decades.

${ }_{25}$ Cyanometallates $^{3}$ form a large and attractive class of compounds displaying a variety of properties. ${ }^{4}$ Among many reported examples, 3D Prussian blue type coordination networks have been extensively studied..$^{5}$ Within this variety of compounds, cyanocuprates based on $\mathrm{d}^{10} \mathrm{Cu}(\mathrm{I})$ cation are interesting entities.

${ }_{30}$ Whereas, owing to their kinetic inertness, dicyanoaurate and dicyanoargentate form mainly discrete species, cyanocuprate generates a variety of extended architectures through selfbridging processes. It is interesting to note that, whereas in dicyanometallates $(\mathrm{M}(\mathrm{I})=\mathrm{Ag}, \mathrm{Au})$ the metal adopts a linear

35 coordination geometry, for cyanocuprate, several geometries such as linear $\left[\mathrm{Cu}^{\mathrm{I}}(\mathrm{CN})_{2}\right]^{-}$, trigonal $\left[\mathrm{Cu}^{\mathrm{I}}(\mathrm{CN})_{3}\right]^{2-}$ and tetrahedral $\left[\mathrm{Cu}^{\mathrm{I}}(\mathrm{CN})_{4}\right]^{3-}$ are encountered (Scheme 1 top). ${ }^{6}$ Furthermore, owing to the ambivalent nature of the cyanide ligand, the latter adopts different coordination modes such as end-to-end 40 (bridging) or end-on ( $\mu_{2}$ or $\mu_{3}$-bridging) as illustrated in scheme 1 (bottom). Finally, due to cuprophilic interactions ${ }^{7}$ between $\mathrm{d}^{10}$ $\mathrm{Cu}(\mathrm{I})$ centres, the formation of dimers displaying luminescence ${ }^{8}$ has been reported.

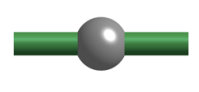

Linear

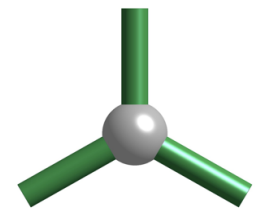

Trigonal

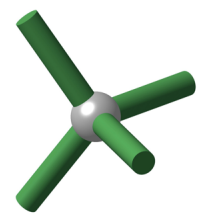

Tetrahedral
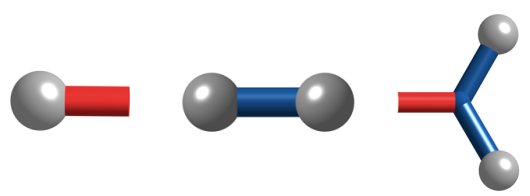

Terminal $\mathrm{M}-\mathrm{CN}$

Bridging $\mathrm{M}-\mathrm{CN}-\mathrm{M}$

$\mu_{2}$ $\mu_{2}$-Bridging NC-MM

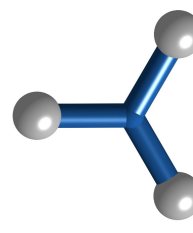

Scheme 1: Schematic representations of the three most encountered 45 coordination geometry around $\mathrm{Cu}(\mathrm{I})$ cation (top); bridging modes of $\mathrm{CN}^{-}$ anion (bottom) in cyanocuprates. Grey spheres represent a $\mathrm{Cu}(\mathrm{I})$ centre, blue and red cylinders represent bridging and terminal cyanide respectively.

50 Applying the concepts developed in molecular tectonics, ${ }^{9}$ an approach dealing with the formation of infinite networks between complementary tectons ${ }^{10}$ or building blocks capable of mutual interconnection, we have explored combinations of discrete cyanometallate with organic cationic tectons. ${ }^{11}$ These 55 combinations, based on strong charge assisted hydrogen bonds, ${ }^{12}$ led to the formation of a variety H-bonded networks displaying various dimensionalities. ${ }^{13}$ For example, combinations of some of bisamidinium dications $\left(\left[\mathbf{X}-2 \mathrm{H}^{+}\right], \mathrm{X}=1-6\right.$, see scheme 2$)$ with linear $\left(\mathrm{M}^{\mathrm{I}}(\mathrm{CN})_{2}{ }^{-}(\mathrm{M}=\mathrm{Ag}\right.$ or $\mathrm{Au})$ leads to luminescent crystals. ${ }^{14}$ ${ }_{60}$ Examples of other luminescent $\mathrm{Ag}(\mathrm{CN})_{2}{ }^{-}$or $\mathrm{Au}(\mathrm{CN})_{2}{ }^{-}$) based architectures stabilized by $\mathrm{H}$ bonds and metallophilic interactions have been also reported. ${ }^{15}$ On the other hand, some of their associations with octahedral $\mathrm{M}^{\mathrm{III}}(\mathrm{CN})_{6}{ }^{3-}(\mathrm{M}=\mathrm{Fe}, \mathrm{Co}$ or $\mathrm{Cr})$ cyanometallates leads to porous crystals. ${ }^{16}$ 


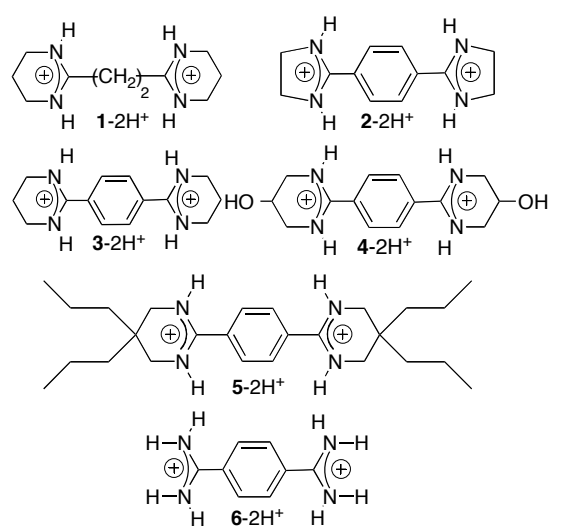

Scheme 2: Dicationic bisamidinium compounds 1-6.

Based on our previous studies mentioned above, we have investigated the formation of extended architectures using 5 dicyanocuprate. In particular, we were interested in exploring the possibility of stabilizing discrete $\mathrm{Cu}(\mathrm{CN})_{2}{ }^{-}$unit through the formation of $\mathrm{H}$-bonded networks using dicationic tectons of the bis-cyclic amidinium type ${ }^{17}$ Here we report on combinations of $\mathrm{KCu}(\mathrm{CN})_{2}{ }^{18}$ with organic compounds $\mathrm{X}-2 \mathrm{H}^{+}(\mathrm{X}=1-6)$ in 10 solution and in the solid state using mechanochemistry, ${ }^{19}$ leading to seven crystalline materials characterized by both X-ray diffraction on single crystals (XRD) and X-ray diffraction on powders (PXRD).

\section{Experimental section}

${ }_{15}$ FT-IR spectra were recorded on a Perkin Elmer ATR spectrometer.

Microanalyses were performed by the Service de Microanalyses de la Fédération de Recherche Chimie, Université de Strasbourg, Strasbourg, France.

\section{${ }_{20}$ Materials}

$\mathrm{KCu}(\mathrm{CN})_{2}$ was synthesized following a reported procedure. ${ }^{18}$

Bisamidinium dications 1-6 have been used either as their $\mathrm{HCl}$ or $\mathrm{TsOH}$ ( $p$-toluenesulfonic acid) salts. Compounds 1-2TsOH, ${ }^{16} \mathbf{3}$ $2 \mathrm{HCl},{ }^{13 \mathrm{a}, \mathrm{b}, 17}$ 4-2 $\mathrm{HCl},{ }^{16}, \mathbf{5}-2 \mathrm{TsOH}^{13 \mathrm{~d}}$ and $\mathbf{6}-2 \mathrm{TsOH}^{20}$ have been 25 prepared as described. The synthesis of $2-2 \mathrm{HCl}$ is described below.

Whereas crystalline materials A-F were colourless, G was found to be orange.

The synthesis by mechanochemistry employed for the preparation 30 of polycrystalline materials A-G was based on the grinding, at room temperature, of mixtures of $0.1 \mathrm{mmol}$ of bisamidinium salts $\left(\mathrm{X}-2 \mathrm{H}^{+}, 2 \mathrm{Y}^{-}, \mathrm{X}=1-6 ; \mathrm{Y}=\mathrm{Cl}^{-}\right.$or $\left.\mathrm{TsO}^{-}\right)$and $0.2 \mathrm{mmol}$ of $\mathrm{KCu}(\mathrm{CN})_{2}$ using a Retsch MM400 shaker mill with a $5 \mathrm{ml}$ agate vessel and two $5 \mathrm{~mm}$ agate balls. In all cases, the powder 35 obtained was washed with water $(50 \mathrm{ml}), \mathrm{MeOH}(10 \mathrm{ml})$ and dried in air, and only characterized using PXRD.

\section{Synthesis of 2-2HCl}

A mixture of 1,4-dicyanobenzene (1 eq., $15.6 \mathrm{mmol}, 2 \mathrm{~g}$ ) and 1,2diaminoethane (2 eq., $31.2 \mathrm{mmol}, 1.88 \mathrm{~g}$ ) and of $\mathrm{P}_{2} \mathrm{~S}_{5}(15 \mathrm{mg})$ as 40 catalys $^{21}$ was heated to $120{ }^{\circ} \mathrm{C}$ under a gentle flux of argon during 1.5 hours. The solid thus obtained was cooled and acidified with an aqueous $\mathrm{HCl}$ solution $(1 \mathrm{~N})$ until $\mathrm{pH} 5$ was reached. After $15 \mathrm{~min}$ of stirring, the mixture was filtered and the filtrate evaporated. The pure compound $2-2 \mathrm{HCl}$ was obtained in ${ }_{45} 80 \%$ yield as a slightly yellowish solid upon crystallizations from distilled water. ${ }^{1} \mathrm{H}-\mathrm{NMR}\left(\mathrm{D}_{2} \mathrm{O}+t \mathrm{BuOH}, 300 \mathrm{MHz}, 25{ }^{\circ} \mathrm{C}, \delta\right.$ ppm): 3.98 (m, 8H, CH$-\mathrm{NH}$ ); 7.93 (s, 4H, CH arom.); ${ }^{13} \mathrm{C}-\mathrm{NMR}$ $\left(\mathrm{D}_{2} \mathrm{O}+t \mathrm{BuOH}, 75 \mathrm{MHz}, 25^{\circ} \mathrm{C}, \delta \mathrm{ppm}\right): 45.0\left(\mathrm{CH}_{2}-\mathrm{NH}\right) ; 153.0$ (CH arom.); $\mathrm{mp}=300{ }^{\circ} \mathrm{C}$ decomp.; ES MS: $\mathrm{m} / \mathrm{z}$ : found 108.16 , 50 calculated: 108.14 . Elemental analysis (\%): calc. for $\mathrm{C}_{12} \mathrm{H}_{16} \mathrm{Cl}_{2} \mathrm{~N}_{4}$. $3 \mathrm{H}_{2} \mathrm{O}: \mathrm{C}=42.23 ; \mathrm{H}=6.49 ; \mathrm{N}=16.42$; found: $\mathrm{C}=43.01 ; \mathrm{H}=$ $6.40 ; \mathrm{N}=16.32$.

Synthesis of network $\mathrm{A}\left(\left[3-2 \mathrm{H}^{+}\right]\left[\mathrm{Cu}(\mathrm{CN})_{2}{ }^{-}\right]_{2}\right)$

The network $\mathbf{A}$ was obtained at $25{ }^{\circ} \mathrm{C}$ in a crystallization tube $(8$ $55 \mathrm{~mm}$ diameter) upon layering a solution of $3-2 \mathrm{HCl} 3 \mathrm{H}_{2} \mathrm{O}(3.7 \mathrm{mg}$, $0.01 \mathrm{mmol})$ in distilled $\mathrm{H}_{2} \mathrm{O}(3 \mathrm{ml})$ with a solution of $\mathrm{KCu}(\mathrm{CN})_{2}$ (3.1 $\mathrm{mg}, 0.02 \mathrm{mmol}$ ) in distilled $\mathrm{H}_{2} \mathrm{O}(5 \mathrm{ml})$. After one day, crystals of formula $\left[\mathrm{C}_{14} \mathrm{H}_{20} \mathrm{~N}_{4}\right]\left[\mathrm{Cu}(\mathrm{CN})_{2}\right]_{2}$ were formed $(81 \%$ yield).

${ }_{60}$ Elemental analysis: calc. (\%) for $\mathrm{C}_{18} \mathrm{H}_{20} \mathrm{~N}_{8} \mathrm{Cu}_{2}: \mathrm{C}=45.46 ; \mathrm{H}=$ 4.24; $\mathrm{N}=23.57$. Found: $\mathrm{C}=46.08 ; \mathrm{H}=4.54 ; \mathrm{N}=23.45$. IR data $\left(\mathrm{cm}^{-1}\right): 3375,3323,3034,3012,2970,2365,2342,2128,2111$, 1738, 1654, 1426, 1354, 1218, 1198, 857, 658.

Using the same stoichiometry, this compound was also obtained ${ }_{65}$ in $70 \%$ yield as a microcrystalline powder by mechanochemistry upon grinding a mixture of the two powders during 10 minutes at $25 \mathrm{~Hz}\left(37 \mathrm{mg}, 0.1 \mathrm{mmol}\right.$ for $3-2 \mathrm{HCl} \cdot 3 \mathrm{H}_{2} \mathrm{O}$ and $31 \mathrm{mg}, 0.2 \mathrm{mmol}$ for $\left.\mathrm{KCu}(\mathrm{CN})_{2}\right)$.

Synthesis of network $\mathrm{B}\left(\left[\mathbf{5}-2 \mathrm{H}^{+}\right]\left[\mathrm{Cu}_{2}(\mathrm{CN})_{3}{ }^{-}\right]_{2}\right)$

70 The network $\mathbf{B}$ was obtained at $25{ }^{\circ} \mathrm{C}$ in a crystallization tube $(8$ mm diameter) upon layering a solution of $5-2 \mathrm{TsOH} 2 \mathrm{H}_{2} \mathrm{O}(7.6$ $\mathrm{mg}, 0.01 \mathrm{mmol})$ in distilled $\mathrm{CH}_{3} \mathrm{OH}(3 \mathrm{ml})$ with a solution of $\mathrm{KCu}(\mathrm{CN})_{2}(3.1 \mathrm{mg}, 0.02 \mathrm{mmol})$ in distilled $\mathrm{H}_{2} \mathrm{O}(3 \mathrm{ml})$. After two days, crystals of the following formula $\left[\mathrm{C}_{26} \mathrm{H}_{44} \mathrm{~N}_{4}\right]\left[\mathrm{Cu}_{2}(\mathrm{CN})_{3}\right]_{2}$. ${ }_{5} 2 \mathrm{CH}_{3} \mathrm{OH}$ were formed (67\% yield).

Elemental analysis: calc. (\%) for $\mathrm{C}_{34} \mathrm{H}_{52} \mathrm{~N}_{10} \mathrm{O}_{4} \mathrm{Cu}_{4}$ : C $=46.04 \%$; $\mathrm{H}=5.91 ; \mathrm{N}=15.79$. Found: $\mathrm{C}=46.16 ; \mathrm{H}=6.02 ; \mathrm{N}=15.75 \%$. IR data $\left(\mathrm{cm}^{-1}\right): 3375,3325,3034,3014,2970,2365,2342,2131$, 2116, 1738, 1654, 1466, 1426, 1366, 1218, 1203, 856, 647.

${ }_{80}$ Using the same stoichiometry, this compound was also obtained in $56 \%$ yield as a microcrystalline powder by mechanochemistry upon grinding a mixture of the two powders during 10 minutes at $25 \mathrm{~Hz}\left(76 \mathrm{mg}, 0.1 \mathrm{mmol}\right.$ for $5-2 \mathrm{TsOH} 2 \mathrm{H}_{2} \mathrm{O}$ and $31 \mathrm{mg}, 0.2$ $\mathrm{mmol}$ for $\left.\mathrm{KCu}(\mathrm{CN})_{2}\right)$.

${ }_{85}$ Synthesis of network $\left.\mathrm{C}\left(\left[4-2 \mathrm{H}^{+}\right]\left[\mathrm{Cu}_{3}(\mathrm{CN})_{4}\right]_{2}\right]_{2}\right)$

The network $\mathbf{C}$ was obtained at $25{ }^{\circ} \mathrm{C}$ in a crystallization tube $(8$ $\mathrm{mm}$ diameter) upon layering a solution of $4-2 \mathrm{HCl} \cdot 3 \mathrm{H}_{2} \mathrm{O}(2.2 \mathrm{mg}$, $0.006 \mathrm{mmol})$ in distilled $\mathrm{H}_{2} \mathrm{O}(3 \mathrm{ml})$ with a solution of $\mathrm{KCu}(\mathrm{CN})_{2}$ (1.9 $\mathrm{mg}, 0.012 \mathrm{mmol})$ in distilled $\mathrm{H}_{2} \mathrm{O}(3 \mathrm{ml})$. After one day, ${ }_{90}$ crystals of the following formula $\left[\mathrm{C}_{14} \mathrm{H}_{20} \mathrm{~N}_{4} \mathrm{O}_{2}\right]\left[\mathrm{Cu}_{3}(\mathrm{CN})_{4}\right]_{2}$ corresponding to the solid state material $\mathbf{C}$ were formed $(15 \%$ yield). The isolated crystals were found to be stable outside the mother liquor. However, upon standing in solution for 2 days, the crystalline material was converted into a yellow powder which 95 could not be structurally characterized.

Elemental analysis: calc. (\%) for $\mathrm{C}_{22} \mathrm{H}_{20} \mathrm{~N}_{12} \mathrm{O}_{2} \mathrm{Cu}_{6}: \mathrm{C}=30.52 ; \mathrm{H}$ $=2.33 ; \mathrm{N}=19.41$. Found: $\mathrm{C}=31.82 ; \mathrm{H}=2.26 ; \mathrm{N}=19.52 \%$. The discrepancy between the calculated and determined \% for $\mathrm{C}$ was observed on several attempts. IR data $\left(\mathrm{cm}^{-1}\right): 3486,3365,3283$, 100 3246, 3228, 3219, 3179, 3052, 2971, 2108, 2099, 2065, 1748, $1659,1600,1515,1466,1366,1337,1307,1228,1218,1109$, $1019,900,856,732,647$ and 597. 
Using the same stoichiometry, only the yellow powder was obtained by mechanochemistry in $50 \%$ yield as a microcrystalline powder upon grinding during 10 minutes at 25 $\mathrm{Hz}$ the mixture of the two solids $(37 \mathrm{mg}, 0.1 \mathrm{mmol}$ for 4$52 \mathrm{HCl} \cdot 3 \mathrm{H}_{2} \mathrm{O}$ and $31 \mathrm{mg}, 0.2 \mathrm{mmol}$ for $\left.\mathrm{KCu}(\mathrm{CN})_{2}\right)$.

Synthesis of network $D\left(\left[6-2 \mathrm{H}^{+}\right]\left[\mathrm{Cu}_{2}(\mathrm{CN})_{4}{ }^{2-}\right]\right)$

The network $\mathbf{D}$ was obtained at $25{ }^{\circ} \mathrm{C}$ in a crystallization tube $(8$ $\mathrm{mm}$ diameter) upon layering a solution of 6-2Ts $\mathrm{OH} 2 \mathrm{H}_{2} \mathrm{O}(2.1$ $\mathrm{mg}, 0.004 \mathrm{mmol})$ in distilled $\mathrm{H}_{2} \mathrm{O}(3 \mathrm{ml})$ with a solution of ${ }_{10} \mathrm{KCu}(\mathrm{CN})_{2}(1.2 \mathrm{mg}, 0.008 \mathrm{mmol})$ in distilled $\mathrm{H}_{2} \mathrm{O}(3 \mathrm{ml})$. After one week, crystals of the following formula $\left[\mathrm{C}_{8} \mathrm{H}_{12} \mathrm{~N}_{4}\right]\left[\mathrm{Cu}_{2}(\mathrm{CN})_{4}\right]$ were formed (73\% yield).

Elemental analysis: calc. (\%) for for $\mathrm{C}_{12} \mathrm{H}_{12} \mathrm{~N}_{8} \mathrm{Cu}_{2}: \mathrm{C}=34.98 ; \mathrm{H}$ $=3.52 ; \mathrm{N}=24.48$. Found: $\mathrm{C}=34.44 ; \mathrm{H}=3.25 ; \mathrm{N}=24.43$. IR 15 data $\left(\mathrm{cm}^{-1}\right): 3377,2978,2964,2116,2099,2068,1653,1592$, $1515,1466,1371,1333,1307,1228,1218,1109,1019,900,863$, $813732,633,514$.

Using the same stoichiometry, this compound was also obtained in $66 \%$ yield as a microcrystalline powder by mechanochemistry 20 upon grinding a mixture of the two powders during 10 minutes at $25 \mathrm{~Hz}\left(53 \mathrm{mg}, 0.1 \mathrm{mmol}\right.$ for $\mathbf{6}-2 \mathrm{TsOH} 2 \mathrm{H}_{2} \mathrm{O}$ and $31 \mathrm{mg}, 0.2$ $\mathrm{mmol}$ for $\left.\mathrm{KCu}(\mathrm{CN})_{2}\right)$.

Synthesis of network $\mathrm{E}\left(\left[1-2 \mathrm{H}^{+}\right]\left[\mathrm{Cu}(\mathrm{CN})_{2}^{-}\right]_{2}\right)$

The network $\mathbf{E}$ was obtained at $25{ }^{\circ} \mathrm{C}$ in a crystallization tube $(8$

${ }_{25} \mathrm{~mm}$ diameter) upon layering a solution of $1-2 \mathrm{TsOH} 3 \mathrm{H}_{2} \mathrm{O}(2.7$ $\mathrm{mg}, 0.005 \mathrm{mmol})$ in distilled $\mathrm{H}_{2} \mathrm{O}(4 \mathrm{ml})$ with a solution of $\mathrm{KCu}(\mathrm{CN})_{2}(1.5 \mathrm{mg}, 0.001 \mathrm{mmol})$ in a $\mathrm{H}_{2} \mathrm{O} / \mathrm{MeOH} 1 / 1$ mixture (4 $\mathrm{ml})$. Crystals of compound $\mathbf{E}\left(\left[\mathrm{C}_{10} \mathrm{H}_{20} \mathrm{~N}_{4}\right]\left[\mathrm{Cu}(\mathrm{CN})_{2}\right]_{2}\right)$ were obtained overnight ( $23 \%$ yield). The isolated crystals were found 30 to be stable outside the mother liquor. However, upon standing in $\mathrm{H}_{2} \mathrm{O} / \mathrm{MeOH}$ solution for a longer period of time (2 days), the compound $\mathbf{E}$ was found to be partially converted into the compound $\mathbf{F}$ without complete conversion. It is worth noting that we were unable to prepare the compound $\mathbf{E}$ by 35 mechanochemistry.

Elemental analysis: calc. (\%) for $\mathrm{C}_{14} \mathrm{H}_{20} \mathrm{~N}_{8} \mathrm{Cu}_{2}$ : $\mathrm{C}=39.34 ; \mathrm{H}=$ 4.72; $\mathrm{N}=26.21$. Found: $\mathrm{C}=41.40 ; \mathrm{H}=4.63 ; \mathrm{N}=26.05$. Again, the discrepancy between the calculated and determined \% for $\mathrm{C}$ was observed on several attempts. IR data $\left(\mathrm{cm}^{-1}\right)$ : 3266, 3228, 40 3189, 3045, 2108, 2096, 2078, 1639, 1609, 1484, 1461, 1317, 1257, 1126, 1094, 990, 837, 732, 687, 643 and 476.

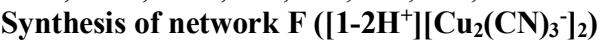

The network $\mathbf{F}$ was obtained at $25{ }^{\circ} \mathrm{C}$ in a crystallization tube $(8$ $\mathrm{mm}$ diameter) upon layering a solution of 1-2 $\mathrm{TsOH} 3 \mathrm{H}_{2} \mathrm{O}(2.7$

$45 \mathrm{mg}, 0.005 \mathrm{mmol})$ in distilled $\mathrm{H}_{2} \mathrm{O}(3 \mathrm{ml})$ with a solution of $\mathrm{KCu}(\mathrm{CN})_{2}(1.5 \mathrm{mg}, 0.01 \mathrm{mmol})$ in distilled $\mathrm{H}_{2} \mathrm{O}(3 \mathrm{ml})$. After four days, crystals of the following formula $\left[\mathrm{C}_{10} \mathrm{H}_{20} \mathrm{~N}_{4}\right]\left[\mathrm{Cu}_{2}(\mathrm{CN})_{3}\right]_{2} \cdot 2 \mathrm{H}_{2} \mathrm{O}$ were formed (38\% yield).

Elemental analysis: calc. (\%) for $\mathrm{C}_{16} \mathrm{H}_{24} \mathrm{~N}_{10} \mathrm{Cu}_{4} \mathrm{O}_{2}: \mathrm{C}=29.90 ; \mathrm{H}$ ${ }_{50}=3.76 ; \mathrm{N}=21.80$. Found: $\mathrm{C}=29.40 ; \mathrm{H}=3.45 ; \mathrm{N}=22.36$. IR data $\left(\mathrm{cm}^{-1}\right): 3609,3540,3365,3300,3261,3201,3075,2953$, 2923, 2852, 2125, 2106, 2080, 1671, 1609, 1483, 1448, 1381, $1319,1285,1213,1185,1128,1111,1092,1014,992,841,781$, $774,700,647,625,518$ and 476.

${ }_{55}$ Using the same stoichiometry, this compound was also obtained in $30 \%$ yield as a microcrystalline powder by mechanochemistry upon grinding a mixture of the two powders during 10 minutes at $25 \mathrm{~Hz}\left(54 \mathrm{mg}, 0.1 \mathrm{mmol}\right.$ for $1-2 \mathrm{TsOH} 3 \mathrm{H}_{2} \mathrm{O}$ and $31 \mathrm{mg}, 0.2$ $\mathrm{mmol}$ for $\left.\mathrm{KCu}(\mathrm{CN})_{2}\right)$.

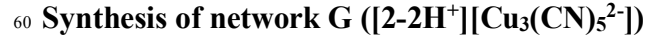

The network $\mathbf{G}$ was obtained in a crystallization tube $(8 \mathrm{~mm}$ diameter) at $25{ }^{\circ} \mathrm{C}$ upon layering a solution of $2-2 \mathrm{HCl}(2.6 \mathrm{mg}$, $0.01 \mathrm{mmol})$ in distilled $\mathrm{H}_{2} \mathrm{O}(3 \mathrm{ml})$ with a solution of $\mathrm{KCu}(\mathrm{CN})_{2}$ (3.1 mg, $0.02 \mathrm{mmol}$ ) in distilled $\mathrm{H}_{2} \mathrm{O}(3 \mathrm{ml})$. Orange crystals of 65 formula $\left[\mathrm{C}_{12} \mathrm{H}_{16} \mathrm{~N}_{4}\right]\left[\mathrm{Cu}_{3}(\mathrm{CN})_{5}\right]$ appeared after one day $(78 \%$ yield).

Elemental analysis: calc. (\%) for $\mathrm{C}_{17} \mathrm{H}_{16} \mathrm{~N}_{9} \mathrm{Cu}_{3}: \mathrm{C}=38.02 ; \mathrm{H}=$ 3.00; $\mathrm{N}=23.47$. Found: $\mathrm{C}=37.51 ; \mathrm{H}=3.17 ; \mathrm{N}=22.60$. IR data $\left(\mathrm{cm}^{-1}\right): 3315,2973,2107,2094,2083,2059,1607,1592,1555$, $701505,1363,1283,1281,1193,1037,987,950,912,843,685$, 614,461 and 423.

Using the same stoichiometry, this compound was also obtained in $80 \%$ yield as a microcrystalline powder by mechanochemistry upon grinding a mixture of the two powders during 10 minutes at $7525 \mathrm{~Hz}(26 \mathrm{mg}, 0.1 \mathrm{mmol}$ for $2-2 \mathrm{HCl}$ and $31 \mathrm{mg}, 0.2 \mathrm{mmol}$ for $\left.\mathrm{KCu}(\mathrm{CN})_{2}\right)$.

Structural studies

Single-Crystal Studies.

Data were collected at 173(2) K on a Bruker SMART CCD 80 diffractometer equipped with an Oxford Cryosystem liquid $\mathrm{N}_{2}$ device, using graphite-monochromated Mo-K $\alpha(\lambda=0.71073 \AA)$ radiation. For all structures, diffraction data were corrected for absorption. Structures were solved using SHELXS-97 and refined by full matrix least-squares on $F^{2}$ using SHELXL-97. The 85 hydrogen atoms were introduced at calculated positions and refined using a riding model. ${ }^{22}$

In most, but not all, cases, carbon and nitrogen atoms of the cyano groups were found to be disordered. When required by crystallographic symmetry, occupancies of $50 \%$ carbon and $50 \%$ 90 nitrogen were used; otherwise relative carbon and nitrogen occupancies were refined. The former and latter cases are indicated in the text as symmetrically and non-symmetrically disordered atoms, respectively. For structural parameters see table 1 .

\section{${ }_{95}$ Powder diffraction studies (PXRD)}

Diagrams were collected on a Bruker D8 diffractometer using monochromatic $\mathrm{Cu}-\mathrm{K} \alpha$ radiation with a scanning range between 3.8 and $30^{\circ}$ using a scan step size of $2 \% \mathrm{mn}$. For powder patterns, see figures $1-7$.

\section{${ }_{100}$ Results and discussion}

All six tectons 1-6 were combined with the potassium salt of dicyanocuprate $\mathrm{KCu}(\mathrm{CN})_{2},{ }^{18}$ under the same crystallization conditions $\left(25{ }^{\circ} \mathrm{C}\right.$, in either $\mathrm{H}_{2} \mathrm{O}$ or $\mathrm{H}_{2} \mathrm{O} / \mathrm{MeOH}$ mixture in the case of $\mathbf{B}$ and $\mathbf{E}$ ). All crystalline materials have been 105 characterized by X-ray diffraction on single crystals (see table $1)^{23}$ and their purity checked by X-ray diffraction on crystalline powders (see figures 1-7).

Since structural characteristics (distances and angles) for the organic tectons 1-6 were close to those previously reported for 110 other combinations, ${ }^{14-17}$ they will not be discussed in detail here. As often observed for cyanocuprates, for the bridging cyanide, owing to close electron density, the $\mathrm{C}$ and $\mathrm{N}$ atoms cannot be easily distinguished by $\mathrm{X}$-ray diffraction. However, by considering that $d(\mathrm{Cu}-\mathrm{C})<d(\mathrm{Cu}-\mathrm{N})$, in some cases the nature of 115 the two atoms could be assigned. For fully disordered cases, as 
observed for $\mathrm{CuCN},{ }^{24}$ they can not be assigned and were labelled $\mathrm{X}$ in the crystallographic files.

Table 2: Representation of the observed building block for the formation of networks A-G.
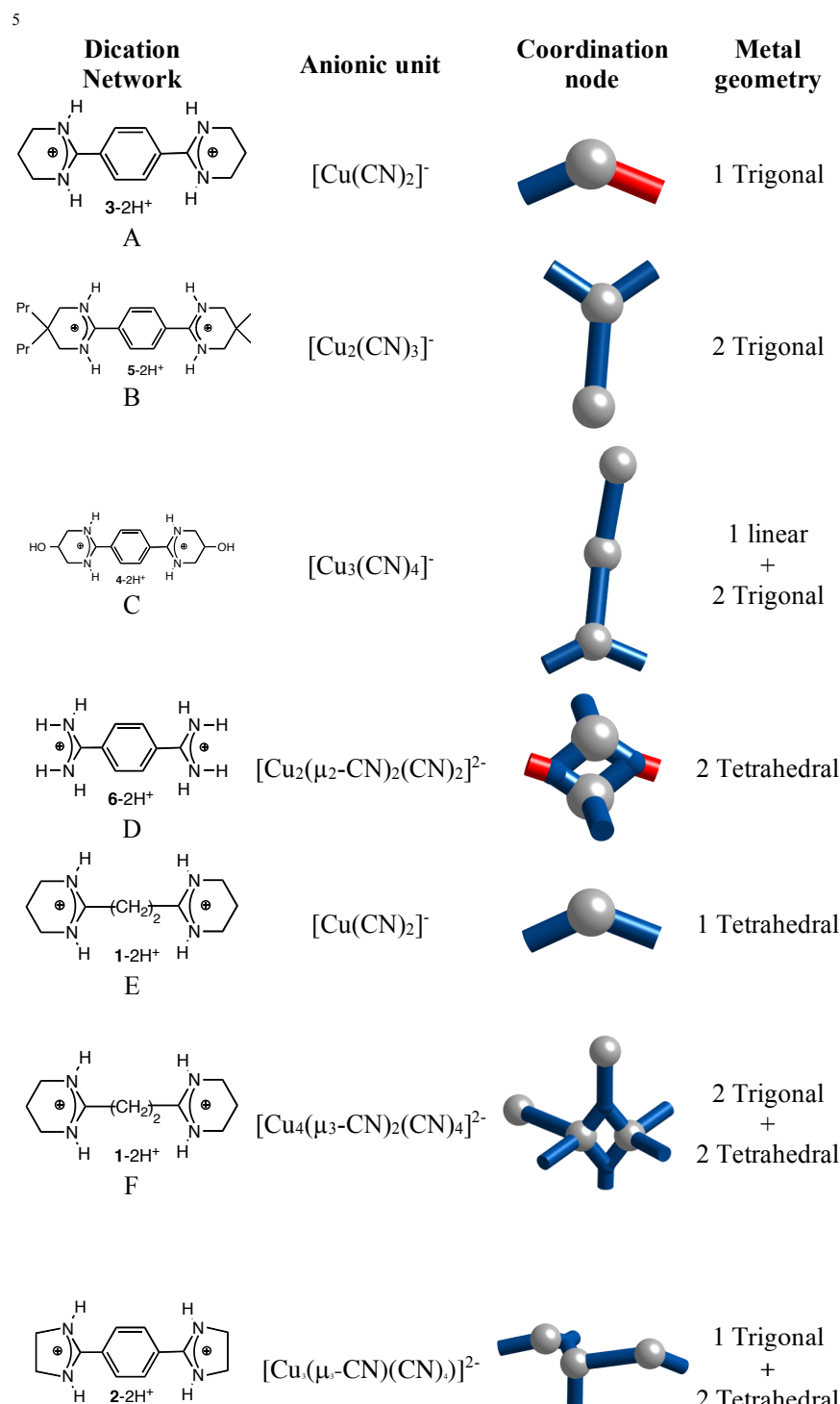

$\left.\left[\mathrm{Cu}_{3}\left(\mu_{3}-\mathrm{CN}\right)(\mathrm{CN})_{4}\right)\right]^{2-}$

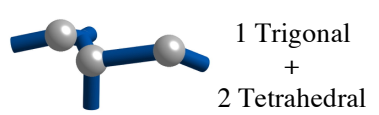

$\mathrm{G}$

The combination of $\mathrm{KCu}(\mathrm{CN})_{2}$ with $3-2 \mathrm{HCl} \cdot 3 \mathrm{H}_{2} \mathrm{O}$ leads to formation of crystals $\mathbf{A}\left(\left[\mathrm{C}_{14} \mathrm{H}_{20} \mathrm{~N}_{4}\right]\left[\mathrm{Cu}(\mathrm{CN})_{2}\right]_{2}\right)$. Crystals were exclusively composed of $\mathrm{Cu}^{+}$cation, $\mathrm{CN}^{-}$anion and the organic tecton $3-2 \mathrm{H}^{+}$(Table 1). No solvent molecules were found to be 10 present in the crystalline material. The structural study revealed that $\mathrm{Cu}^{+}$and $\mathrm{CN}^{-}$ions form a zig-zag type 1D anionic network along the $b$ axis (Fig. 1 left) with $\left[\mathrm{Cu}(\mathrm{CN})_{2}\right]^{-}$units as repeating structural node (Table 2). Within the network, two types of $\mathrm{CN}^{-}$ moieties (terminal and bridging) are encountered. The $\mathrm{Cu}(\mathrm{I})$ 15 center adopts a deformed trigonal geometry with $\mathrm{C}-\mathrm{Cu}-\mathrm{N}$ angles varying between $110.82(7)^{\circ}$ and $133.53(8)^{\circ}$. The $\mathrm{Cu}-\mathrm{C}$ distances are equal to $1.9056(19) \AA$ and 1.9033(18) $\AA$ for the bridging and terminal cyanides respectively. The $\mathrm{Cu}-\mathrm{N}$ distance is equal to 2.0143(17) $\AA$. For the $\mathrm{CN}^{-}$anion, two $\mathrm{CN}$ distances of 1.148(2) $\AA$
20 and 1.152(3) $\AA$ are observed. Within the anionic network, the $\mathrm{Cu}$ $\mathrm{Cu}$ distance between consecutive cations is $4.765 \AA$. It is worth noting that, the $1 \mathrm{D}$ network obtained is the same as the one observed for $\mathrm{KCu}(\mathrm{CN})_{2} .^{18}$

The bisamidinium cation 3 behaves as a H-bond donor unit and 25 interconnects consecutive anionic 1D networks along the $a$ axis leading thus to the extension of the dimensionality of the architecture from 1D (coordination network) to 2D (Fig. 1 middle). The interconnection occurs through both electrostatic attractive interactions and by $\mathrm{H}$-bonding between the dicationic 30 tecton $3-2 \mathrm{H}^{+}$and two terminal cyanides $\left(\mathrm{d}_{\mathrm{N}-\mathrm{N}}=2.835(3) \AA\right)$, and two bridging cyanides $\left(\mathrm{d}_{\mathrm{N}-\mathrm{N}}=3.105(4) \AA\right)$. Within the $2 \mathrm{D}$ arrangement, the shortest $\mathrm{Cu}-\mathrm{Cu}$ distance, between two consecutive $1 \mathrm{D}$ arrays is $8.656 \AA$. Consecutive planes are packed in staggered fashion along the $c$ axis with the shortest $\mathrm{Cu}-\mathrm{Cu}$ 35 distance of 5.524(4) $\AA$. It is worth noting that under the used conditions, the obtained crystalline phase was pure as demonstrated by the fit between the observed and simulated powder pattern using the single crystal data (Fig. 1 right).

Interestingly, the same crystalline phase $\mathbf{A}$ was obtained by 40 mechanochemistry by grinding a mixture of powders of $\mathrm{KCu}(\mathrm{CN})_{2}$ and $3-2 \mathrm{HCl} 3 \mathrm{H}_{2} \mathrm{O}$.
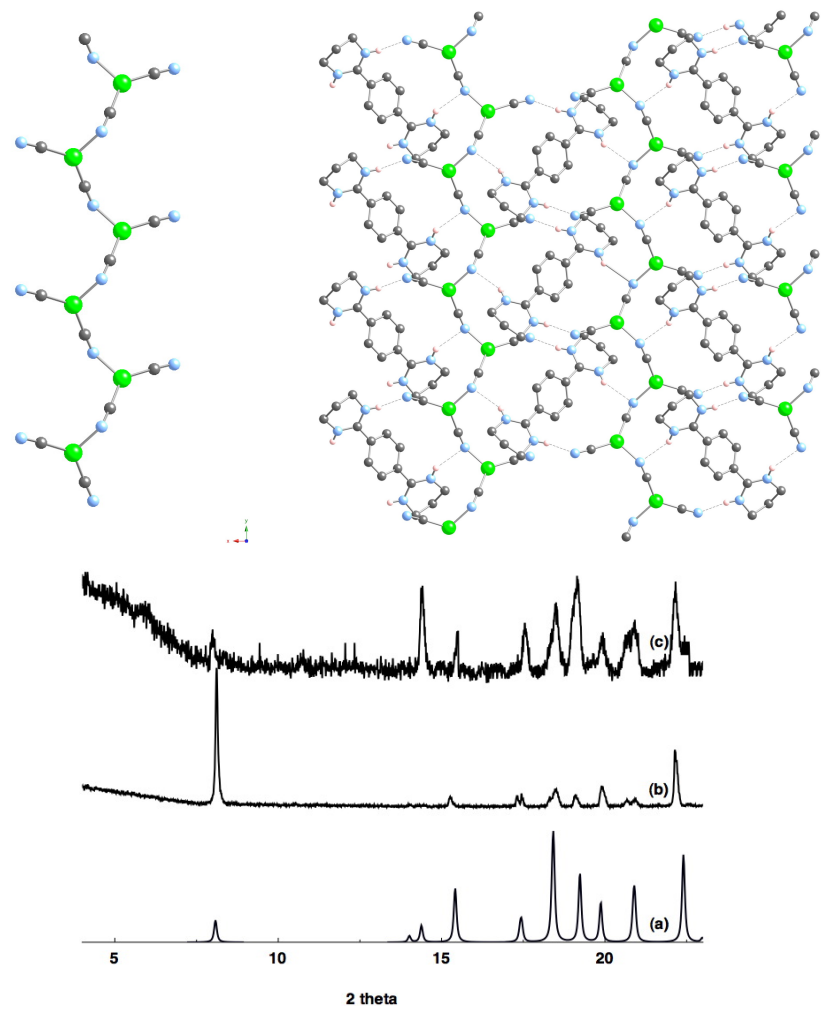

Figure 1: Portions of the structure of $\mathbf{A}$ showing the formation of the anionic 1D cyanocuprate network along the $b$ axis (top left), the interconnection of consecutive $1 \mathrm{D}$ coordination networks into a $2 \mathrm{D}$ 45 arrangement ( $a \mathrm{O} b$ plane) by the dicationic tecton $3-2 \mathrm{H}^{+}$behaving as $\mathrm{H}-$ bond donor (top right) and the comparison between XRPD patterns of the simulated (a), observed using growth in solution (b) and observed using mechanochemistry (c) (bottom). Some of the $\mathrm{H}$ atoms are not shown for clarity and H-bonds are presented by dashed lines.

50

The reaction of $\mathrm{KCu}(\mathrm{CN})_{2}$ with $5-2 \mathrm{TsOH} 2 \mathrm{H}_{2} \mathrm{O}$ leads to the crystalline material B $\left(\left[\mathrm{C}_{26} \mathrm{H}_{44} \mathrm{~N}_{4}\right]\left[\mathrm{Cu}_{2}(\mathrm{CN})_{3}\right]_{2} .2 \mathrm{CH}_{3} \mathrm{OH}\right)$. The crystal (Table 1) is composed of $\mathrm{Cu}^{+}, \mathrm{CN}^{-}$ions, tecton $\mathbf{5}-2 \mathrm{H}^{+}$and 
$\mathrm{MeOH}$ solvent molecules. The same phase was obtained by mechanochemistry by grinding a mixture of powders of 5$2 \mathrm{TsOH} 2 \mathrm{H}_{2} \mathrm{O}$ and $\mathrm{KCu}(\mathrm{CN})_{2}$. The cyanocuprate network is an anionic $2 \mathrm{D}$ honeycomb $(6,3)$ type architecture $^{25}$ resulting from 5 the interconnection of $\mathrm{Cu}(\mathrm{I})$ centres adopting a trigonal coordination geometry by $\mathrm{CN}^{-}$ligands (Fig 2 left). The repeating structural node is a $\left[\mathrm{Cu}_{2}(\mathrm{CN})_{3}\right]^{-}$anionic unit (Table 2). The 2D honeycomb network is the most encountered architecture for cyanocuprates and has been already observed with a variety of 10 positively charged species such as alkali, BEDT-TTF, diammonium, phosphonium and tetraalkylammonium cations. ${ }^{26}$

The $\mathrm{Cu}-\mathrm{X}$ and $\mathrm{X}-\mathrm{Cu}-\mathrm{X}(\mathrm{X}=\mathrm{C}$ or $\mathrm{N})$ distance and angle are in the $1.899(3)-1.933(3) \AA$ and $113.19(12)^{\circ}$ and $129.45(11)^{\circ}$ range respectively. These values are similar to those usually observed 15 for cyanocuprates. A short $\mathrm{Cu}-\mathrm{Cu}$ distance of 4.959(6) $\AA$ is observed within the $2 \mathrm{D}$ architecture. Consecutive anionic sheets are packed in a parallel fashion along the $c$ axis with a slight translation in the (001) plane. The organic tectons $5-2 \mathrm{H}^{+}$are located within the channels and oriented almost perpendicularly 20 to the 2D planes (Fig. 2 middle). They behave as H-bond donor units and form rather weak hydrogen bonds (shortest X-N distance of 3.170(4) $\AA$ ) with the anionic networks. Interestingly, 5-2 $\mathrm{H}^{+}$dications serve as rivets and interconnect two consecutive anionic layers. Thus, their presence does not alter the 25 dimensionality of the architecture that remains 2D. Within the riveted sheets dimer, the shortest $\mathrm{Cu}-\mathrm{Cu}$ distance between the two planes is $6.489(6) \AA$. The riveted sheets dimers are packed in a parallel fashion giving rise to interdigitation through van der Waals contacts (shortest C-C distances of $c a 4.3 \AA$ ) between the 30 pendant propyl chains belonging to the organic tecton $\mathbf{5}-2 \mathrm{H}^{+}$. The distance between two consecutive parallel dimeric sheets is equal to $9.605 \AA$. The disordered methanol molecules, located between anionic planes, form $\mathrm{H}$-bonded dimers with $\mathrm{O}-\mathrm{O}$ distances of 2.205(5) and 2.862(5) $\AA$ and do not interact with the other 35 components.

Under the conditions used, the obtained crystalline phase was pure as demonstrated by the fit between the observed and simulated powder pattern using the single crystal data (Fig. 2 right).

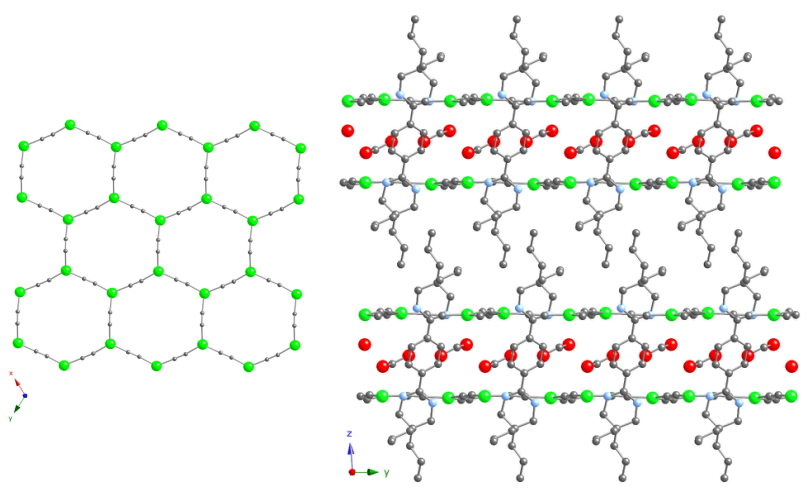

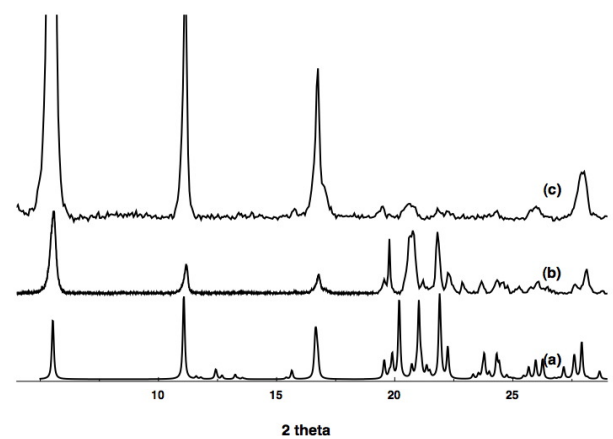

40 Figure 2: Portions of the crystal structure of $\mathbf{B}$, showing the anionic $(6,3)$ cyanocuprate honeycomb network (top left), the localization of the dicationic tecton $5-2 \mathrm{H}^{+}$within the channels and their role as rivet connecting two consecutive anionic sheets and the packing of the sheets dimers along the $c$ axis together with the disordered $\mathrm{MeOH}$ molecules 45 (top right) and the comparison between XRPD patterns of the simulated

(a), observed using growth in solution (b) and observed using mechanochemistry (c) (bottom). H atoms are omitted for clarity.

The reaction of $\mathrm{KCu}(\mathrm{CN})_{2}$ with $4-2 \mathrm{HCl} \cdot 3 \mathrm{H}_{2} \mathrm{O}$ leads to the crystalline material $\mathbf{C}\left(\left[\mathrm{C}_{14} \mathrm{H}_{20} \mathrm{~N}_{4} \mathrm{O}_{2}\right]\left[\mathrm{Cu}_{3}(\mathrm{CN})_{4}\right]_{2}\right)$. Crystals were 50 exclusively composed of $\mathrm{Cu}^{+}$cation, $\mathrm{CN}^{-}$anion and the organic tecton $4-2 \mathrm{H}^{+}$(Table 1). No solvent molecules were found to be present in the crystalline material. As for $\mathbf{B}$, again a $2 \mathrm{D}$ architecture is observed for the cyanocuprate part of the assembly. However, here because of the insertion of a $\mathrm{Cu}(\mathrm{I})$ 55 centre adopting a linear coordination geometry between two $\mathrm{Cu}(\mathrm{I})$ displaying a trigonal environment, the architecture is not of the honeycomb type but an almost planar 2D network offering deformed octagonal channels (Fig. 3 left). The repeating motif is a $\left[\mathrm{Cu}_{3}(\mathrm{CN})_{4}\right]^{-}$unit displaying three crystallographically ${ }_{60}$ independent copper centres (Table 2). The same type of architecture, although rare, has been also previously reported. ${ }^{27}$ As stated above, among the three $\mathrm{Cu}$ centres of $\left[\mathrm{Cu}_{3}(\mathrm{CN})_{4}\right]^{-}$unit, two adopt a trigonal geometry with $\mathrm{X}-\mathrm{Cu}-\mathrm{X}(\mathrm{X}=\mathrm{C}$ or $\mathrm{N})$ angles varying between $131.3(7)^{\circ}$ and $109.6(6)^{\circ}$. For the third one with a ${ }_{65}$ rather rare distorted linear geometry, ${ }^{27}$ the $\mathrm{X}-\mathrm{Cu}-\mathrm{X}$ angle is 164.1(7) ${ }^{\circ}$. The $\mathrm{Cu}-\mathrm{X}$ distances are 1.813(16) $\AA$ and 1.841(18) $\AA$ for the $\mathrm{Cu}$ atom adopting a linear geometry and between 1.894(18) $\AA$ and 1.949(15) $\AA$ for the two with trigonal environment. Within the $2 \mathrm{D}$ arrangement, the $\mathrm{Cu}-\mathrm{Cu}$ distance 70 varies between $4.926 \AA$ and $4.988 \AA$. Consecutive anionic sheets are packed in a parallel fashion along the $a$ axis with a slight translation in the (001) plane leading thus to channels (Fig. 3 middle). Whereas the shortest $\mathrm{Cu}-\mathrm{Cu}$ distance between two consecutive sheets is 2.909(3) $\AA$, the distance between 75 consecutive parallel planes containing the layers is $3.22 \AA$.

The bisamidinium cations are included within the channels and oriented almost perpendicular to the 2D networks. They form weak H-bonds with the cyanide groups (shortest $\mathrm{d}_{\mathrm{NH}-\mathrm{CN}}=$ 3.173(4) $\AA$ ). The $\mathrm{OH}$ groups do not form $\mathrm{H}$ bonds with anionic 80 moieties $\left(\mathrm{d}_{\mathrm{O}-\mathrm{X}}(\mathrm{X}=\mathrm{C}\right.$ or $\left.\mathrm{N})=3.649(6) \AA\right)$, but act as a hydrogen bond acceptor with the $\mathrm{NH}$ groups of neighbouring amidinium molecules $\left(\mathrm{d}_{\mathrm{O}-\mathrm{N}}=2.907(5) \AA\right)$. Interestingly, again the dicationic organic tecton behaves as a rivet and interconnect consecutive sheets. In contrast with $\mathbf{B}$ for which the riveting process connects 85 two consecutive sheets, here the process takes place in an alternate fashion thus leading to interconnection of all consecutive 2D arrangements. Consequently, when taking into 
account both types of connectivity patterns (coordination- and Hbonds), the overall architecture is a 3D network. As in the case of $\mathbf{A}$ and $\mathbf{B}, \mathbf{C}$ forms a single pure crystalline phase as evidenced by the fit between the observed and simulated powder pattern using 5 the single crystal data (Fig. 3 right). It is worth noting that the same phase was obtained by mechanochemistry upon grinding a powder mixture of $4-2 \mathrm{HCl} 3 \mathrm{H}_{2} \mathrm{O}$ and $\mathrm{KCu}(\mathrm{CN})_{2}$.
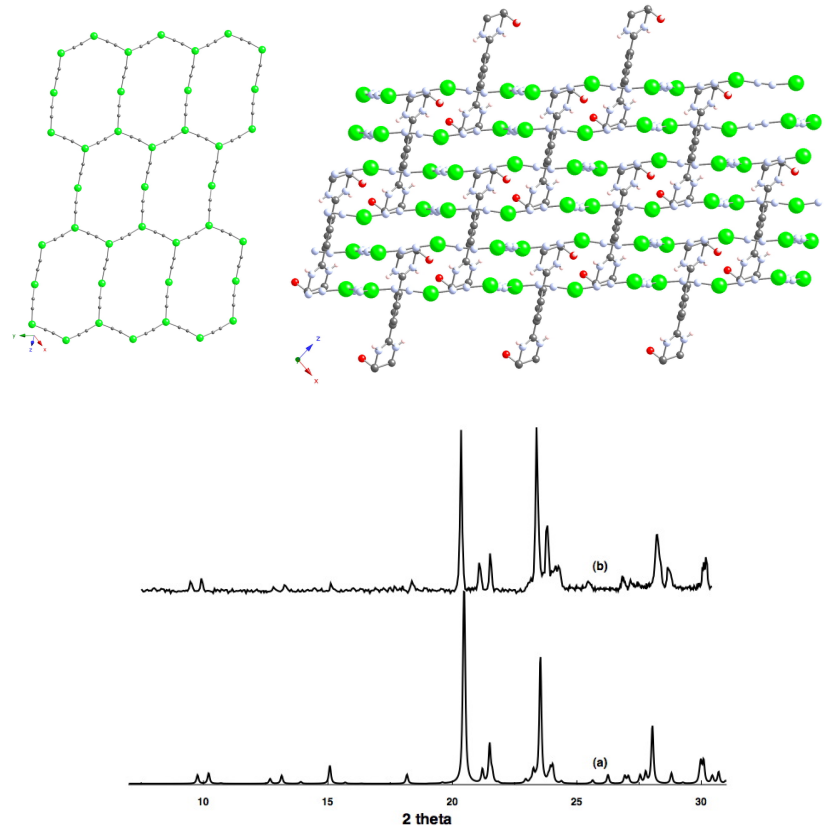

Figure 3: Portions of the crystal structure of $\mathbf{C}$, showing the anionic 10 cyanocuprate network (top left), the localization of the dicationic tecton $5-2 \mathrm{H}^{+}$within the channels and their role as rivet connecting consecutive anionic sheets along the $c$ axis (top right) and the comparison between the simulated (a) and observed (b) powder diffraction patterns showing the purity of the crystalline material (bottom). $\mathrm{H}$ atoms are omitted for clarity.

15 The reaction of $\mathrm{KCu}(\mathrm{CN})_{2}$ with $6-2 \mathrm{TsOH} 2 \mathrm{H}_{2} \mathrm{O}$ leads to the crystalline material D $\left(\left[\mathrm{C}_{8} \mathrm{H}_{12} \mathrm{~N}_{4}\right]\left[\mathrm{Cu}_{2}(\mathrm{CN})_{4}\right]\right)$. The latter is exclusively composed of $\mathrm{Cu}^{+}$cation, $\mathrm{CN}^{-}$anion and tecton $6-2 \mathrm{H}^{+}$ (Table 1). The cyanocuprate part of the structure is a $2 \mathrm{D}$ network (Fig. 4 left) with $\left[\mathrm{Cu}_{2}\left(\mu_{2}-\mathrm{CN}\right)_{2}(\mathrm{CN})_{2}\right]^{2-}$ as the translating building 20 unit (Table 2). This type of 2D arrangement has, to the best of our knowledge, never been described. The latter is composed of a $\mathrm{Cu}$ dimer maintained by two $\mathrm{CN}^{-}$anions in the $\mathrm{C} \mu$-bridging mode and two $\mathrm{CN}^{-}$moieties insuring the connectivity between consecutive dimers within the $2 \mathrm{D}$ assembly. $\mathrm{All} \mathrm{Cu}(\mathrm{I})$ atoms are 25 of the same type adopting a tetrahedral coordination geometry. The $\mathrm{X}-\mathrm{Cu}-\mathrm{X}(\mathrm{X}=\mathrm{C}$ or $\mathrm{N})$ angle varies between $95.54(6)^{\circ}$ and $119.57(8)^{\circ}$ and the $\mathrm{Cu}-\mathrm{X}$ distance is in the 1.9609(18) $2.3688(18) \AA$ range. Within the dimeric unit, the short $\mathrm{Cu}-\mathrm{Cu}$ distance of 2.6153(4) $\AA$ implies cuprophilic interactions. ${ }^{7,8}$ The 30 sheet type architecture displays deformed hexagons with two long $\mathrm{Cu}-\mathrm{X} \equiv \mathrm{X}-\mathrm{Cu}$ and two short $\mathrm{Cu}-\mathrm{Cu}$ distances (Fig. 4 left). The latter distance results from the $\mu_{2}-(\mathrm{CN})$ bridging process. The $2 \mathrm{D}$ arrays are perfectly superimposable along the $c$ axis leading thus to channels with $c a 6.3 \times 6.2 \AA$ dimension based on Van der

35 Waals radii. The organic dications, in marked contrast with compounds $\mathrm{B}$ and $\mathrm{C}$, are not located within channels but rather lay between anionic layers with a tilt angle of $c a 45^{\circ}$ between the plane formed by its aromatic ring and the anionic sheet (figure 4 middle). The organic tecton is H-bonded to both bridging and 40 terminal cyanide anions. Based on $\mathrm{X}-\mathrm{N}$ distances, the H-bond with the terminal $\mathrm{CN}$ is strong (2.891(5) $\AA$ ), whereas the one for the bridging anion is rather weak $(3.305(6) \AA)$. Under the conditions used, the crystalline phase $\mathbf{D}$ was pure as demonstrated by the fit between the observed and simulated powder pattern 45 using the single crystal data (Fig. 4 right). The same phase was also obtained by mechanochemistry upon grinding a mixture of powders of 6-2TsOH $2 \mathrm{H}_{2} \mathrm{O}$ and $\mathrm{KCu}(\mathrm{CN})_{2}$.

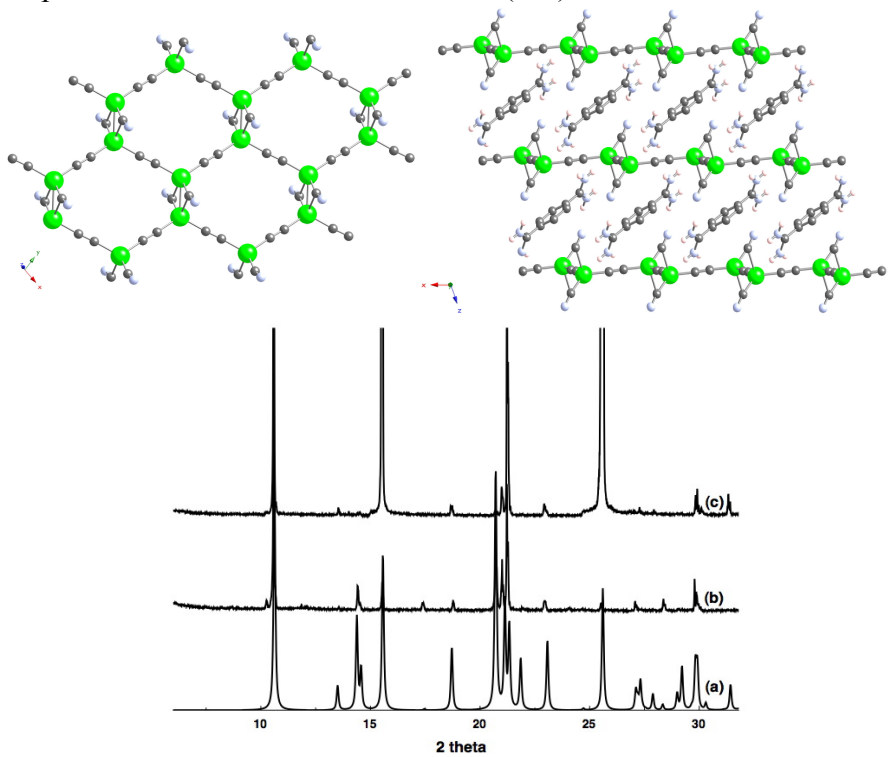

Figure 4: Portions of the crystal structure of $\mathbf{D}$, showing the anionic cyanocuprate network (top left), the localization of the dicationic tecton 50 $6-2 \mathrm{H}^{+}$between consecutive anionic sheets along the $c$ axis (top right) and the comparison between XRPD patterns of the simulated (a), observed using growth in solution (b) and observed using mechanochemistry (c) (bottom). Some $\mathrm{H}$ atoms are omitted for clarity.

The combination of the tecton $1-2 \mathrm{TsOH} 3 \mathrm{H}_{2} \mathrm{O}$ with $\mathrm{KCu}(\mathrm{CN})_{2}$ is 55 rather interesting since it leads to two different architectures $\mathbf{E}$ and $\mathbf{F}$ depending on the experimental conditions used. Whereas the crystalline material $\mathbf{E}$ seems to be the kinetic product, the compound $\mathbf{F}$ is likely the thermodynamic species.

At $25^{\circ} \mathrm{C}$, in a $\mathrm{H}_{2} \mathrm{O} / \mathrm{MeOH}$ mixture, the reaction of $\mathrm{Cu}(\mathrm{CN})_{2}{ }^{-}$with ${ }_{60} \mathbf{1}-2 \mathrm{H}^{+}$(see experimental part) leads overnight to the crystalline material $\mathbf{E}\left(\left[\mathrm{C}_{10} \mathrm{H}_{20} \mathrm{~N}_{4}\right]\left[\mathrm{Cu}(\mathrm{CN})_{2}\right]_{2}\right)$ (Table 1). The latter, when isolated, is a perfectly stable crystalline solid which could be characterized by both XRD and PXRD. However, when left in mother liquor, for 2 days compound $\mathbf{E}$ partially converts into the ${ }_{65}$ compound $\mathbf{F}$. It is worth noting that in contrast with all other 6 crystalline materials, compound $\mathbf{E}$ could not be prepared by mechanochemistry.

The cyanocuprate network is a $3 \mathrm{D}$ diamond type anionic framework (Fig. 5 left) with the $\left[\mathrm{Cu}(\mathrm{CN})_{2}\right]^{-}$unit as the unique 70 structural node (Table 2). This type of architecture has been previously encountered with ammonium cation or copper(II) cationic complexes. ${ }^{24 \mathrm{f}, 28}$

Only one type of tetrahedral $\mathrm{Cu}(\mathrm{I})$ centre is present in the framework. The $\mathrm{Cu}-\mathrm{X}(\mathrm{X}=\mathrm{C}$ or $\mathrm{N})$ distance and $\mathrm{X}-\mathrm{Cu}-\mathrm{X}$ angle 75 vary between 1.9581(17) $\AA$ and 2.0764(16) $\AA$ and 101.61(6) ${ }^{\circ}$ and $114.60(7)^{\circ}$ respectively. The organic dicationic tectons $1-2 \mathrm{H}^{+}$are hosted within the diamondoid cavities ( $c a 8.3 \AA$ diameter) and lay on centre of symmetry centre (Fig. 5 middle). The anionic 3D 
framework and the organic tectons interact through several weak hydrogen bonds with the shortest amidinium/cyanide N-X distance of 3.148(5) A (Fig. 5 middle).

Under the used conditions, the isolated crystalline phase $\mathbf{E}$ was 5 pure as demonstrated by the fit between the observed and simulated powder pattern using the single crystal data (Fig. 5 right).
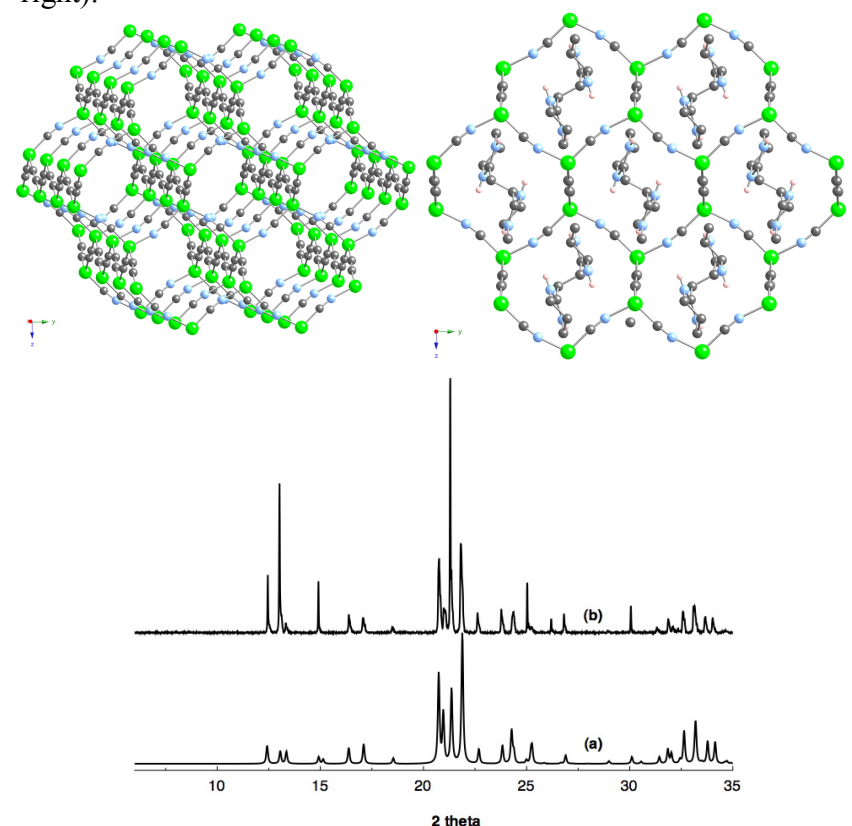

Figure 5: Portions of the crystal structure of $\mathbf{E}$, showing the anionic cyanocuprate 3D diamond type network (top left), the localization of the 10 dicationic tecton $\mathbf{1}-2 \mathrm{H}^{+}$within the anionic cavities (top right) and the comparison between the simulated (a) and observed (b) powder diffraction patterns showing the purity of the crystalline material (bottom). Some of the $\mathrm{H}$ atoms are omitted for clarity.

In contrast to the aforementioned case, in pure water, the 15 combination of $\mathrm{KCu}(\mathrm{CN})_{2}$ with $1-2 \mathrm{TsOH} 3 \mathrm{H}_{2} \mathrm{O}$ leads to the crystalline material $\mathbf{F}\left(\left[\mathrm{C}_{10} \mathrm{H}_{20} \mathrm{~N}_{4}\right]\left[\mathrm{Cu}_{2}(\mathrm{CN})_{3}\right]_{2} .2 \mathrm{H}_{2} \mathrm{O}\right)$ (Table 1). This compound is stable as isolated solid and in aqueous solution. It was also obtained by mechanochemistry upon grinding a mixture of powders of $1-2 \mathrm{TsOH} 3 \mathrm{H}_{2} \mathrm{O}$ and $\mathrm{KCu}(\mathrm{CN})_{2}$.

${ }_{20}$ Compound $\mathbf{F}$, composed of $\mathrm{Cu}^{+}, \mathrm{CN}^{-}$anion, $1-2 \mathrm{H}^{+}$dication and $\mathrm{H}_{2} \mathrm{O}$ solvent molecule, is a $3 \mathrm{D}$ deformed cubic network (Fig. 6 left) with the octahedral $\left[\mathrm{Cu}_{4}\left(\mu_{3}-\mathrm{CN}\right)_{2}(\mathrm{CN})_{4}\right]^{2-}$ moiety as the translating unit (Table 2). The type of cuboid arrangement has been previously described when using protonated dmpa (325 dimethyl-aminopropylamino). ${ }^{29}$

Two types of geometry (tetrahedral and trigonal) for $\mathrm{Cu}(\mathrm{I})$ centres, are observed in the structure. For the one with $\mathrm{Td}$ geometry, two $\mathrm{CN}$ in end-to-end, and two in end-on bridging modes are present. The $\mathrm{Cu}-\mathrm{X}(\mathrm{X}=\mathrm{C}$ or $\mathrm{N})$ distance varies 30 between 1.952(4) $\AA$ and 1.966(5) $\AA$ for the $\mathrm{CN}^{-}$units in end-toend bridging mode and between 2.075(5) $\AA$ and 2.128(5) $\AA$ for disordered $\mathrm{CN}^{-}$anion in end-on bridging mode. The angle around the $\mathrm{Cu}(\mathrm{I})$ atom varies between $114.66(17)^{\circ}$ and $105.34(18)^{\circ}$. The bridging mode leads to the formation of a dimeric $\mathrm{Cu}(\mathrm{I})$ unit $35\left[\mathrm{Cu}_{2}(\mathrm{CN})_{6}\right]^{4-}$ with a rather short $\mathrm{Cu}-\mathrm{Cu}$ distances of $2.4555(11)$ $\AA$. The other $\mathrm{Cu}(\mathrm{I})$ canter in trigonal coordination geometry bridges consecutive dimeric units. The $\mathrm{Cu}-\mathrm{X}(\mathrm{X}=\mathrm{C}$ or $\mathrm{N})$ distance is in the $1.900(4)-1.939(4) \AA$ range and the $\mathrm{XCuX}$ angle of $126.3(2)^{\circ}$ and $123.50(19)^{\circ}$. The dicationic tectons $1-2 \mathrm{H}^{+}$, 40 included in the channels $(7.2 \times 6.4 \AA$, based on Van der Waals radii), interact with the $3 \mathrm{D}$ anionic cyanocuprate framework through several weak H-bonds with $\mathrm{N}-\mathrm{X}$ distance of 3.282(4) $\AA$ (Fig. 6 middle). The two water molecules present in the crystal are also located within the channels and form strong $\mathrm{H}$-bonds 45 with $\mathrm{NH}$ moieties of the bisamidinium cations $\left(\mathrm{d}_{\mathrm{O}-\mathrm{N}}=2.804(6)\right.$ $\AA$ ). Under the conditions used, the crystalline phase $\mathbf{F}$ was pure as demonstrated by the fit between the observed and simulated powder pattern using the single crystal data (Fig. 6 right).
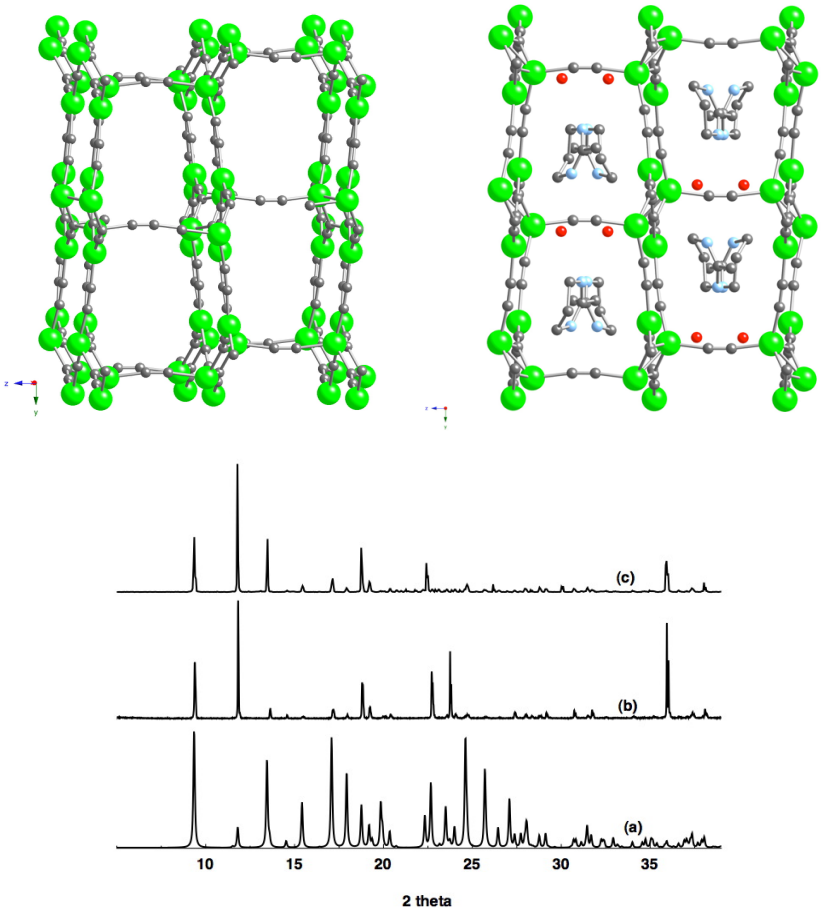

Figure 6: Portions of the crystal structure of $\mathbf{F}$, showing the anionic 50 cyanocuprate $3 \mathrm{D}$ cuboid type network along the a axis (top left), the localization of the dicationic tecton $1-2 \mathrm{H}^{+}$and water molecules within the anionic cavities (top right) and the comparison between XRPD patterns of the simulated (a), observed using growth in solution (b) and observed using mechanochemistry (c) (bottom). $\mathrm{H}$ atoms and $\mathrm{H}_{2} \mathrm{O}$ solvent 55 molecules are not presented for clarity.

The combination of $\mathrm{KCu}(\mathrm{CN})_{2}$ with 2 -2 $\mathrm{HCl}$ leads to the crystalline material $\mathbf{G}\left(\left[\mathrm{C}_{12} \mathrm{H}_{16} \mathrm{~N}_{4}\right]\left[\mathrm{Cu}_{3}(\mathrm{CN})_{5}\right]\right)$. The cyanocuprate framework is a $3 \mathrm{D}$ diamondoid type architecture (Fig. 7 left) with $\left.\left[\mathrm{Cu}_{3}\left(\mu_{3}-\mathrm{CN}\right)(\mathrm{CN})_{4}\right)\right]^{2-}$ as a severely deformed tetrahedral 60 translating unit (Table 2). The type of diamondoid architecture has been previously described when using protonated $\mathrm{me}_{2}$ pip (2 $\mathrm{N}, \mathrm{N}$-dimethylpiperazine). ${ }^{25}$ The crystal (Table 1) is exclusively composed of $\mathrm{Cu}(\mathrm{I}), \mathrm{CN}^{-}$and $2-2 \mathrm{H}^{+}$ions. The anionic portion of the crystal contains one $\mathrm{Cu}(\mathrm{I})$ centre in triangular and two in ${ }_{65}$ tetrahedral environments. Whereas one of the five $\mathrm{CN}^{-}$anions present in the translating node behaves as a end-on bridging ligand, the other four adopt the end-to-end connecting mode. For the $\mathrm{Cu}(\mathrm{I})$ centre with triangular geometry, the $\mathrm{Cu}-\mathrm{X}(\mathrm{X}=\mathrm{C}$ or $\mathrm{N})$ distance ranges between 1.935(2) $\AA$ and 1.949(2) $\AA$ and the ${ }_{70} \mathrm{XCuX}$ angle varies between $117.72(10)^{\circ}$ and $121.63(10)^{\circ}$. For the tetrahedral $\mathrm{Cu}(\mathrm{I})$ atoms, the $\mathrm{Cu}-\mathrm{X}(\mathrm{X}=\mathrm{C}$ or $\mathrm{N})$ distance is in the $1.972(2)-2.252(3) \AA$ range and the $\mathrm{X}-\mathrm{Cu}-\mathrm{X}$ angle varies between $101.99(9)^{\circ}$ and $115.39(9)^{\circ}$. In terms of connectivity, one of the two tetrahedral $\mathrm{Cu}(\mathrm{I})$ centres is connected by $\mathrm{CN}^{-}$ligands to two ${ }_{75} \mathrm{Cu}$ atoms in trigonal geometry and two in tetrahedral environment. The $\mathrm{Cu}(\mathrm{I})$ with trigonal geometry is connected 
through three cyanide anions to three $\mathrm{Cu}(\mathrm{I})$ with $\mathrm{Td}$ environment. As the result of the end-on bridging mode of the two $\mathrm{CN}^{-}$anions, coordinated by two $\mathrm{C}$ and one $\mathrm{N}$ atoms, a dimeric unit is generated with a rather short $\mathrm{Cu}-\mathrm{Cu}$ distance of $2.5195(6) \AA$ 5 indicating again cuprophilic interactions. The anionic 3D deformed diamondoid architecture displays cavities, which are filled with $2-2 \mathrm{H}^{+}$cations (Fig. 7 middle). The latter interact with the cyanocuprate framework through rather weak H-bonds between the amidinium $\mathrm{H}$-bond donor and $\mathrm{CN}$ - acceptor sites 10 (with the shortest X-N distance of $c a 3.154 \AA$ ). Under the used conditions, the crystalline phase $\mathbf{G}$ was pure as demonstrated by the fit between the observed and simulated powder pattern using the single crystal data (Fig. 7 right). It is worth noting that the same compound was obtained by mechanochemistry upon 15 grinding a mixture of powders of $2-2 \mathrm{HCl}$ and $\mathrm{KCu}(\mathrm{CN})_{2}$.

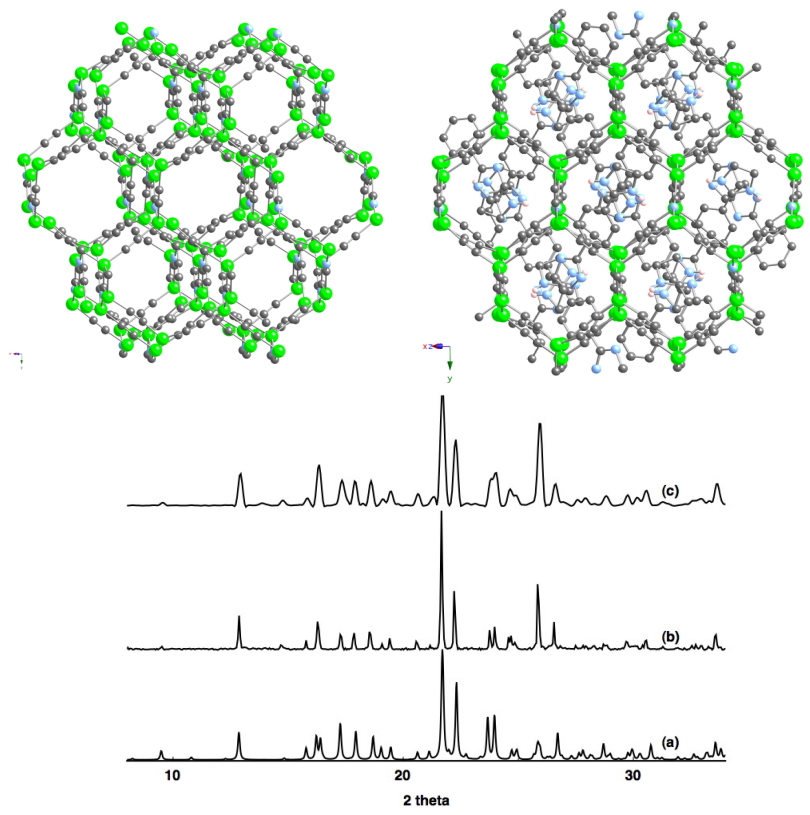

Figure 7: Portions of the crystal structure of G, showing the anionic cyanocuprate 3D diamondoid type network along the $c$ axis (top left), the localization of the dicationic tecton $2-2 \mathrm{H}^{+}$within the anionic cavities (top right) and the comparison between XRPD patterns of the simulated (a), observed using growth in solution (b) and observed using

mechanochemistry (c) (bottom). Some $\mathrm{H}$ atoms are not presented for clarity.

It should be noted that, other related 3D networks based on the particular end-on bridging mode of the cyanide ligand forming ${ }_{25}\left[\mathrm{Cu}_{3}(\mathrm{CN})_{5}\right]^{2-}, \quad\left[\mathrm{Cu}_{4}(\mathrm{CN})_{7}\right]^{3-}$ or $\left[\mathrm{Cu}_{2}(\mathrm{CN})_{3}\right]^{-}$units have been already described. ${ }^{30}$

\section{Conclusions}

In conclusion, upon combining $\mathrm{KCu}(\mathrm{CN})_{2}$ with symmetrical dicationic bisamidinium moieties 1-6 possessing different shapes 30 and geometries, seven (A-G) new coordination networks of the cyanocuprate type displaying 1-, 2- and 3-D dimensionalities have been obtained (Fig. 8). These compounds contain $\mathrm{Cu}^{+}$ cations, $\mathrm{CN}^{-}$anions, organic cationic tectons and, in some cases, solvent molecules. The formation of networks results from the 35 interconnection of $\mathrm{Cu}(\mathrm{I})$ centres by cyanide anions by different bridging modes. For all cases, only two types of building subunit $\left[\mathrm{Cu}_{\mathrm{x}}^{\mathrm{I}}(\mathrm{CN})_{\mathrm{x}+1}\right]^{-}$or $\left[\mathrm{Cu}_{\mathrm{x}}^{\mathrm{I}}(\mathrm{CN})_{\mathrm{x}+2}\right]^{2-}(\mathrm{x}=1-3)$ have been observed. Among the seven networks, when considering only $\mathrm{Cu}-\mathrm{CN}$ type connectivity, one monodimensionnal (A), three bidimensionnal ${ }_{40}(\mathbf{B}, \mathbf{C}$ and $\mathbf{D})$ and three tridimensionnal (E, F and $\left.\mathbf{G}\right)$ architectures have been obtained. For the formation of the above mentioned solid state compounds, the nature of the organic dication appears to play a decisive role (see Fig. 8). For the 1D arrangement $\mathbf{A}$, consecutive networks are interconnected by the 45 tecton $3-2 \mathrm{H}^{+}$through charge-assisted $\mathrm{H}$-bonds leading thus to a $2 \mathrm{D}$ architecture. In the case of $2 \mathrm{D}$ anionic networks $\mathbf{B}, \mathbf{C}$ and $\mathbf{D}$, whereas for tectons $4-2 \mathrm{H}^{+}(\mathbf{B})$ and $\mathbf{5}-2 \mathrm{H}^{+}(\mathbf{C})$ the consecutive sheets are riveted through inclusion of the organic moieties within the honeycomb type channels and establishment of $\mathrm{H}$ ${ }_{50}$ bonds with the anionic cyanocuprate networks, for tecton $6-2 \mathrm{H}^{+}$ (D), the consecutive sheets are interconnected by $\mathrm{H}$-bonds through intercalation of the organic cations between anionic layers. Whereas for $\mathbf{B}$, the riveting process takes place only between two consecutive sheets and thus the overall architecture 55 remains a $2 \mathrm{D}$ arrangement for which the consecutive double layers are separated through interdigitation of the propyl chains, for $\mathbf{C}$, the riveting occurs in an alternating fashion. Consequently, the dimensionality of the architecture is increased to 3 by taking into account both $\mathrm{H}$ - and coordination-bonding processes. The ${ }_{60}$ same holds for the intercalated arrangement D. Finally, for the 3D cyanocuprate networks ( $\mathbf{E}, \mathbf{F}$ and $\mathbf{G})$, the organic dications, forming $\mathrm{H}$ bonds with some of the cyanide moieties, are included within the channels.

Combinations of other bisamidinium type dicationic tectons with ${ }_{65}\left[\mathrm{CuCN}_{2}\right]^{-}$anion are currently under investigation.

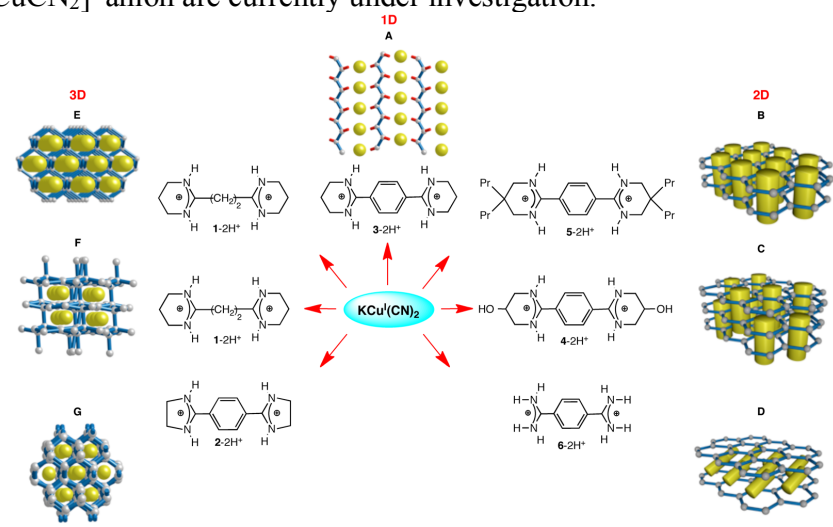

Figure 8: Summary of all seven cyanocuprate type networks (A-G)

formed upon combining the organic dicationic tectons $\mathbf{X}-2 \mathrm{H}^{+}(\mathrm{X}=1-6)$ with $\mathrm{Cu}(\mathrm{CN})_{2}{ }^{-}$. The yellow cylinders and spheres represent schematically 70 the organic dications and their localization within the structures.

\section{Acknowledgement}

We thank the Universite de Strasbourg, the International Centre for Frontier Research in Chemistry (FRC), Strasbourg, the Institut Universitaire de France, the Ministry of Education and Research 75 and the CNRS for financial support.

\section{Notes and references}

${ }^{a}$ Molecular Tectonics Laboratory, UMR UdS-CNRS 7140, University of Strasbourg, Institut Le Bel, 4, rue Blaise Pascal, F-67000 Strasbourg,

France; E-mail:ferlay@unistra.fr, hosseini@unistra.fr

$80{ }^{b}$ Present adress: CRPP, Centre de Recherche Paul Pascal, 115 Avenue Schweitzer 33600 PESSAC, France

$\dagger$ Electronic Supplementary Information (ESI) available: Crystal data of A-G have been deposited at the Cambridge Crystallographic Data Centre (CCDC 924952 - 924958). See DOI: 10.1039/b000000x/ 
1 (a) S. R. Batten and R. Robson, Angew. Chem. Int. Ed., 1998, 37, 1460-1494; (b) A. J. Blake, N. R. Champness, P. Hubberstey, W.-S. Li, M. A. Withersby and M. Schröder, Coord. Chem. Rev.,1999, 193, 117-138; (c) M. W. Hosseini in NATO ASI Series, Eds. D. Braga, F. Grepiono, G. Orpen, Serie C, Kluwer, Dordrecht, Netherlands, 1999, 538, 181-208; (d) B. Moulton and M. J. Zaworotko, Chem. Rev., 2001, 101, 1629-1658; (e) M. Eddaoui, D.B. Moler, H. Li, B. Chen, T.M. Reineke, M. O'Keefe and O. M. Yaghi, Acc. Chem. Res., 2001, 34, 319-330; (f) G. F. Swiegers and T. J. Malefetse, Chem. Rev., 2000, 100, 3483-3538; (g) C. Janiak Dalton Trans., 2003, 2781$2804 ;$

2 (a) S. Kitagawa, R. Kitaura and S. Noro, Angew. Chem., Int. Ed. 2004, 43 2334-2375; (b) G. Ferey Chem. Soc. Rev., 2008, 37, 191214; (c) Chem. Soc. Rev., 2009, 38, themed issue on metal-organic frameworks; (d) C. Janiak and J. K. Vieth New. J. Chem. 2010, 34, 2366-2388 ; (e) Chem. Rev., 2012, 112, Metal-Organic Frameworks special issue.

3 (a)A.G. Sharpe 1976 "The chemistry of cyano complexes of the transition metals". London, UK: Academic Press; (b) K. R. Dunbar, and R. Heintz, A. Prog. Inorg. Chem., 1996, 45, 283-373; (c) T. Iwamoto 1996. Comprehensive Supramolecular Chemistry, Vol. 6, edited by D. D. MacNicol, F. Toda \& R. Bishop, ch. 19, pp. 643-690.

4 (a) S. Ohkoshi, K-I. Arai, Y. Sato, and K. Hashimoto Nature Materials, 2004, 3, 857-861; (b) M. R. Hartman, V. K. Peterson, Y. Liu, S. S. Kaye and J. R. Long Chem. Mater., 2006, 18, 3221-3224; (c) S. Ohkoshi, H. Tokoro, T. Matsuda, H. Takahashi, H. Irie, and K. Hashimoto Angew. Chem. Int. Ed,. 2007, 46, 3238-3241; (d) J. M. Herrera, A. Bachschmidt, F. Villain, A. Bleuzen, V. Marvaud, W. Wernsdorfer and M. Verdaguer Phil. Trans. R. Soc. A, 2008, 366, 127-138.

5 (a) J. L. Heinrich, P. A. Berseth and J. R. Long, Chem. Commun., 1998, 1231-1232; (b) S. S. Kaye and J. R. Long, J. Am. Chem. Soc., 2005, 127, 6506-6507; (c) L. Reguera, C.P. Krap, J. Balmaseda and E. Reguera, J. Phys. Chem. C, 2008, 112, 15893-15899.

6 J. K.Burdett and O. Eisenstein, Inorg. Chem. 1992, 31, 1758-1762.

7 (a) F. B. Stocker, T. P. Staeva, C. M. Rienstra and D. Britton, Inorg. Chem., 1999, 38, 984-991 ; (b) H. L. Hermann, G. Boche and P. Schwerdtfeger, Chem. Eur. J., 2001, 7, 5333-5342.

8 X. Li, Z. Pan, D. A.Welch, F. Baril-Robert, R. D. Pike and H. H. Patterson, J. Phys. Chem. C, 2012, 116, 26656-26667.

9 (a) S. Mann Nature, 1993, 365, 499-505; (b) M. W. Hosseini Acc. Chem. Res., 2005, 38, 313-323.

10 (a) M. Simard, D. Su, and J. D. Wuest, J. Am. Chem. Soc., 1991, 113, 4696-4698; (b) M. W. Hosseini, CrystEngComm., 2004, 6, 318-322; (c) M. W. Hosseini,; Chem. Commun., 2005, 582-583.

11 S. Ferlay and M. W. Hosseini, in "Functional supramolecular architectures for organic electronics and nanotechnology", ed. P. Samori and F. Cacialli, Wiley-VCH, 2010.

12 (a) K. T. Holman, S. M. Martin, D. P. Parker and M. D. Ward, J. Am. Chem. Soc. 2001, 123, 4421-4424; (b) K. T. Holman, A. M. Pivovar and Ward, M. D. Science 2001, 294, 1907-1911; (c) S. A. Dalrymple and G. K. H. Shimizu, J. Am. Chem. Soc., 2007, 129, 12114-12116; (d) M. J. Horner, K. T. Holman and M. D. Ward, J. Am. Chem. Soc. 2007, 129, 14640-14660; (e) M. W. Hosseini, Coord. Chem. Rev. 2003, 240, 157-166.

13 (a) S. Ferlay, O. Félix, M. W. Hosseini, J.-M. Planeix and N. Kyritsakas Chem. Commun., 2002, 702-703; (b) S. Ferlay, V. Bulach, O. Félix, M. W. Hosseini, J.-M. Planeix and N. Kyritsakas, CrystEngComm, 2002, 4, 447-453; (c) S. Ferlay, R. Holakovsky, M. W. Hosseini, J.-M. Planeix and N. Kyritsakas, Chem. Commun., 2003, 1224-1225; (d) P. Dechambenoit, S. Ferlay, M. W. Hosseini, J.-M. Planeix and N. Kyritsakas New J. Chem., 2006, 30, 1403-1410; (e) P. Dechambenoit, S. Ferlay, M. W. Hosseini and N. Kyritsakas, Chem. Commun., 2007, 4626-4628; (f) P. Dechambenoit, S. Ferlay,
M. W. Hosseini and N. Kyritsakas, Chem. Commun., 2009, 67986800.

14 (a) C. Paraschiv, S. Ferlay, V. Bulach and J.-M. Planeix, Chem. Comm, 2004, 2270-2269; (b) P. Dechambenoit, S. Ferlay, B. Donnio, D. Guillon and M.W. Hosseini, Chem. Commun., 2011, 734-736; (c) P. Dechambenoit, S. Ferlay, M. W. Hosseini and N. Kyritsakas, CrystEngComm, 2011, 13, 1922-1930.

15 (a) H. Schmidbaur Chem. Soc. Rev., 1995, 24, 391-400; (b) M. Stender, M.M. Olmstead, A.L. Balch, D. Rios and S. Attar, Dalton Trans. 2003, 4282-4287; (c) J. Lefebvre, R. J. Batchelor and D. B. Leznoff, J. Am. Chem. Soc. 2004, 126, 16117-16125; (d) H. D. Guo, X. M. Guo, S. R. Batten, J. F. Song, S. Y. Song, S. Dang, G. L. Zheng, J. K. Tang, and H. J. Zhang, Cryst. Growth Des., 2009, 9, 1394-1401.

16 P. Dechambenoit, S. Ferlay, M. W. Hosseini and N. Kyritsakas, J. Am. Chem. Soc., 2008, 130,17106-17113.

17 (a) O. Félix, M. W. Hosseini, A. De Cian and J. Fischer, New J. Chem., 1998, 22, 1389-1393; (b) . Félix, M. W. Hosseini, A. De Cian and J. Fischer, J. Chem. Soc., Chem. Commun., 2000, 281-282.

18 (a) D. T. Cromer, J. Phys. Chem. 1957, 61, 1388-1392 ; (b) J. D. Graybeal, and G. L. McKown, Inorg. Chem. 1966, 5, 1909-1913; (c) C. Kappenstein and R. P. Hugel, Inorg. Chem. 1977, 16, 250-254; (d) S. M. Liu, C. E. Plecnik, E. A. Meyers and S. G. Shore, Inorg. Chem. 2005, 44, 282-292; (e) X. P. Zhou, W. X. Ni, S. Z. Zhan, J. Ni, D. Li and Y-G. Yin, Inorg. Chem. 2007, 46, 2345-2347.

19 (a) T. J. Friščić Mater. Chem. 2010, 20, 7599-7605 ; (b) S. L. James, C. J. Adams, C. Bolm, D. Braga, P. Collier, T. Friščić, F. Grepioni, K. D. M. Harris, G. Hyett, W. Jones, A. Krebs, J. Mack, L. Maini, A. G. Orpen, I. P. Parkin, W. C. Shearouse, J. W. Steed and D. C. Waddell, Chem. Soc. Rev. 2012, 41, 413-447.

20 P. Oxley and W. F. Short, J. Chem. Soc., 1947, 497-505.

21 A. B. P. Lever, B. S. Ramaswamy, S. H. Simonsen and L. K. Thompson, Can. J. Chem., 1970, 48, 3076-3088.

22 G. M. Sheldrick, Programs for the Refinement of Crystal Structures, University of Göttingen, Göttingen, Germany, 1996.

23 Crystal data of A-G have been deposited at the Cambridge Crystallographic Data Centre (CCDC 924952 - 924958).

24 S. Kroeker, R. E. Wasylishe and J. V. Hanna, J. Am. Chem. Soc. 1999, 121, 1582-1590.

25 A. F. Wells, Three-dimensional Nets and Polyhedra, WileyInterscience, New York, 1997.

26 (a) D. T. Cromer and A. C. Larson, Acta Crystallogr. 1962, 15, $397-$ 403; (b) U. Geiser, H. H. Wang, K. D. Carlson, J. M. Williams, H. A. Charlier, J. E. Heindl, G. A. Yaconi, B. J. Love, M. W. Lathrop, D. L. Overmyer, J. Ren and M. H. Whangbo, Inorg. Chem. 1991, 30, 2587-2588; (c) C. Jernák, K. Györyová and S. Sabolová, Inorg. Chim. Acta, 1991, 185, 119-125; (d) F. B. Stocker, T. P. Staeva, C. M. Rienstra and D. Britton, Inorg. Chem. 1999, 38, 984-991; (e) Y. Zhao, M. Hong, W. Su, R. Cao, Z. Zhuo and A. S. C. Chan, Dalton, 2000, 1685-1686 ; (f) E. Colacio, R. Kivekas, F. Lloret, M. Sunberg, J. Suarez-Varela, M. Bardaji and A. Laguna, Inorg. Chem. 2002, 41, 5141-5149 ; (g) T. Pretsch, I. Brüdgam and H. Z. Hartl, Anorg. Allg. Chem. 2003, 629, 942-944 ; (h) T. Pretsc, and H. Z. Hartl, Anorg. Allg. Chem. 2004, 630, 1581-1588 ; (i) S. Yun, H. S. Moon, C. H. Kim and S-G. Lee, J. Coord. Chem., 2004, 57, 321-327 ; (j) S-H. Lin, X-P. Zhou, D. Li, and S. Weng Ng Cryst. Gr. Des., 2008, 3879-3881.

27 G. A. Bowmaker, H. Hartl and V. Urban, Inorg. Chem., 2000, 39, 4548-4554; (b) A.H. Pohl, A M. Chippindale and S. J. Hibble, Sol. St. Sciences, 2006, 8, 379-387.

28 R. J. Williams, A. C. Larson, and D. T. Cromer, Acta Crystallogr. Sect. B 1972, 28, 858-864;

29 Y-L. Qin, J-J. Hou, L. Lu and X-M. Zhang, Cryst. Growth Des. 2011, 11, 3101-3108.

30 (a) H. Yuge and T. Iwamoto, J. Incl. Phen. Macro. Chem. 1996, 26, 119-126; (b) H. Deng, Y. Qiu, C. Daiguebonne, N. Kerbellec,. O. 
Guillou, M. Zeller and S. R. Batten, Inorg. Chem., 2008, 47 5866-

5872; (c) K-M. Park, S. Lee, Y. Kang, S-H. Moon and S. S. Lee,

Dalton, 2008, 6521-6523. 
Table 1 : Crystallographic Parameters for crystals A-G recorded at $173 \mathrm{~K}$.

\begin{tabular}{|c|c|c|c|c|c|c|c|}
\hline Formula & $\begin{array}{c}\mathbf{A} \\
\mathrm{C}_{9} \mathrm{H}_{10} \mathrm{CuN}_{4} \\
\end{array}$ & $\begin{array}{c}\mathbf{B} \\
\mathrm{C}_{17} \mathrm{H}_{26} \mathrm{Cu}_{2} \mathrm{~N}_{5} \mathrm{O} \\
\end{array}$ & $\begin{array}{c}\mathbf{C} \\
\mathrm{C}_{11} \mathrm{H}_{10} \mathrm{Cu}_{3} \mathrm{~N}_{6} \mathrm{O} \\
\end{array}$ & $\begin{array}{c}\mathbf{D} \\
\mathrm{C}_{12} \mathrm{H}_{12} \mathrm{Cu}_{2} \mathrm{~N}_{8} \\
\end{array}$ & $\begin{array}{c}\mathbf{E} \\
\mathrm{C}_{7} \mathrm{H}_{10} \mathrm{CuN}_{4} \\
\end{array}$ & $\begin{array}{c}\mathbf{F} \\
\mathrm{C}_{16} \mathrm{H}_{24} \mathrm{Cu}_{4} \mathrm{~N}_{10} \mathrm{O}_{2} \\
\end{array}$ & $\begin{array}{c}\mathbf{G} \\
\mathrm{C}_{17} \mathrm{H}_{16} \mathrm{Cu}_{3} \mathrm{~N}_{9} \\
\end{array}$ \\
\hline Molecular weight & 237.75 & 443.51 & 432.87 & 395.38 & 213.73 & 642.61 & 537.01 \\
\hline Crystal system & Monoclinic & Triclinic & Triclinic & Triclinic & Monoclinic & Orthorhombic & Monoclinic \\
\hline Space group & $\mathrm{P} 2(1) / \mathrm{c}$ & $\mathrm{P}-1$ & $\mathrm{P}-1$ & $\mathrm{P}-1$ & $\mathrm{P} 2(1) / \mathrm{n}$ & Pbcn & $\mathrm{P} 2(1) / \mathrm{n}$ \\
\hline $\mathrm{a}(\AA)$ & $12.3350(3)$ & $8.3378(7)$ & $8.5782(15)$ & $6.6681(3)$ & $8.4930(2)$ & $12.1846(4)$ & $10.7515(3)$ \\
\hline $\mathrm{b}(\AA)$ & $7.7340(2)$ & $8.4859(7)$ & $9.0487(16)$ & $6.7635(3)$ & $8.3120(3)$ & $14.9832(4)$ & 12.6791(3) \\
\hline$c(\AA)$ & $11.4860(3)$ & $16.0299(15)$ & $9.1472(16)$ & $8.9552(4)$ & $11.7280(3)$ & $13.1581(4)$ & $13.7566(4)$ \\
\hline$\alpha(\operatorname{deg})$ & 90 & $93.171(3)$ & $96.855(4)$ & $96.837(2)$ & 90 & 90 & 90 \\
\hline$\beta(\operatorname{deg})$ & $117.5791(13)$ & $92.107(3)$ & $97.5510(10)$ & $108.930(2)$ & $94.3450(19)$ & 90 & $93.894(2)$ \\
\hline$\gamma(\operatorname{deg})$ & 90 & $115.690(2)$ & $105.014(4)$ & $99.618(2)$ & 90 & 90 & 90 \\
\hline $\mathrm{V}\left(\AA^{3}\right)$ & $971.24(4)$ & $1018.17(15)$ & $678.7(2)$ & $370.11(3)$ & $825.54(4)$ & $2402.20(13)$ & $1870.96(9)$ \\
\hline $\mathrm{Z}$ & 4 & 2 & 2 & 1 & 4 & 4 & 4 \\
\hline Colour & colourless & colourless & colourless & colourless & colourless & colourless & orange \\
\hline Crystal $\operatorname{dim}\left(\mathrm{mm}^{3}\right)$ & $\begin{array}{c}0.15 \times 0.14 \times \\
0.11\end{array}$ & $\begin{array}{c}0.16 \times 0.14 \times \\
0.10\end{array}$ & $\begin{array}{c}0.04 \times 0.04 \times \\
0.02\end{array}$ & $\begin{array}{c}0.10 \times 0.07 \times \\
0.06\end{array}$ & $\begin{array}{c}0.08 \times 0.06 \times \\
0.05\end{array}$ & $0.12 \times 0.08 \times 0.06$ & $\begin{array}{c}0.12 \times 0.08 \times \\
0.06\end{array}$ \\
\hline $\mathrm{D}_{\text {alk }}\left(\mathrm{gcm}^{3}\right)$ & 1.626 & 1.447 & 2.118 & 1.774 & 1.720 & 1.777 & 1.906 \\
\hline $\mathrm{F}(000)$ & 484 & 458 & 426 & 198 & 436 & 1288 & 1072 \\
\hline$\mu(\mathrm{mm})$ & 2.211 & 2.102 & 4.663 & 2.881 & 2.590 & 3.527 & 3.404 \\
\hline Wavelength $(\AA)$ & 0.71073 & 0.71073 & 0.71073 & 0.71073 & 0.71073 & 0.71073 & 0.71073 \\
\hline $\begin{array}{c}\text { Number of data } \\
\text { meas. }\end{array}$ & 3092 & 11641 & 4934 & 2561 & 4342 & 27778 & 19934 \\
\hline $\begin{array}{l}\text { Number of data } \\
\text { with } I>2_{\text {all }}\end{array}$ & $\begin{array}{c}2508[\mathrm{R}(\mathrm{int})= \\
0.0201]\end{array}$ & $\begin{array}{c}4633[\mathrm{R}(\mathrm{int})= \\
0.0296]\end{array}$ & $\begin{array}{c}3413[\mathrm{R}(\mathrm{int})= \\
0.0388]\end{array}$ & $\begin{array}{c}1573[\mathrm{R}(\mathrm{int})= \\
0.0152]\end{array}$ & $\begin{array}{c}2621[\mathrm{R}(\mathrm{int})= \\
0.0190]\end{array}$ & $\begin{array}{c}2769[\mathrm{R}(\mathrm{int})= \\
0.0418]\end{array}$ & $\begin{array}{c}4513[\mathrm{R}(\mathrm{int})= \\
0.0356]\end{array}$ \\
\hline $\mathrm{R}$ & $\begin{array}{c}\mathrm{R} 1=0.0330, \\
\mathrm{wR} 2=0.0843\end{array}$ & $\begin{array}{c}\mathrm{R} 1=0.0400, \\
\mathrm{wR} 2=0.0978\end{array}$ & $\begin{aligned} \mathrm{R} 1 & =0.1009 \mathrm{wR} 2 \\
& =0.2637\end{aligned}$ & $\begin{array}{l}\mathrm{R} 1=0.0210, \\
\mathrm{wR} 2=0.0601\end{array}$ & $\begin{array}{c}\mathrm{R} 1=0.0322, \\
\mathrm{wR} 2=0.0771\end{array}$ & $\begin{aligned} \mathrm{R} 1= & 0.0423, \mathrm{wR} 2 \\
& =0.1163\end{aligned}$ & $\begin{array}{r}\mathrm{R} 1=0.0298, \\
\mathrm{wR} 2=0.0721\end{array}$ \\
\hline $\mathrm{R}_{\mathrm{W}}$ & $\begin{array}{l}\text { R1 }=0.0454, \\
\text { wR2 }=0.0898\end{array}$ & $\begin{array}{l}\mathrm{R} 1=0.0579, \\
\mathrm{wR} 2=0.1045\end{array}$ & $\begin{array}{c}\text { R1 = 0.1613, } \\
\text { wR2 }=0.2909\end{array}$ & $\begin{array}{l}\mathrm{R} 1=0.0219, \\
\mathrm{wR} 2=0.0605\end{array}$ & $\begin{array}{c}\mathrm{R} 1=0.0452, \\
\mathrm{wR} 2=0.0836\end{array}$ & $\begin{array}{c}\mathrm{R} 1=0.0522, \mathrm{wR} 2 \\
=0.1257\end{array}$ & $\begin{array}{r}\mathrm{R} 1=0.0430, \\
\mathrm{wR} 2=0.0767\end{array}$ \\
\hline GOF & 1.042 & 1.034 & 1.244 & 1.074 & 1.029 & 1.030 & 1.037 \\
\hline $\begin{array}{l}\text { Largest peak in } \\
\text { final difference } \\
\left(\mathrm{e}^{3}\right)\end{array}$ & 0.347 and -0.454 & 0.779 and -0.585 & 1.386 and -1.937 & $\begin{array}{c}0.455 \text { and - } \\
0.324\end{array}$ & $\begin{array}{l}0.432 \text { and - } \\
0.993\end{array}$ & 1.252 and -0.936 & $\begin{array}{l}0.907 \text { and }- \\
0.857\end{array}$ \\
\hline
\end{tabular}




\section{Graphical Abstract}

Upon combining $\mathrm{KCu}(\mathrm{CN})_{2}$ with symmetrical dicationic bisamidinium, seven new coordination networks of the cyanocuprate type displaying 1-, 2- and 3-D dimensionalities have been obtained. In these architectures, the cyanocuprate species and the bisamidinium organic tectons behave as $\mathrm{H}$-bond acceptors and donors respectively. The connectivity between cyanide anions and $\mathrm{Cu}(\mathrm{I}) \mathrm{cations}$ leading ${ }_{5}$ to different anionic extended cyanocuprate coordination assemblies is strongly influenced by the nature of the organic tectons.

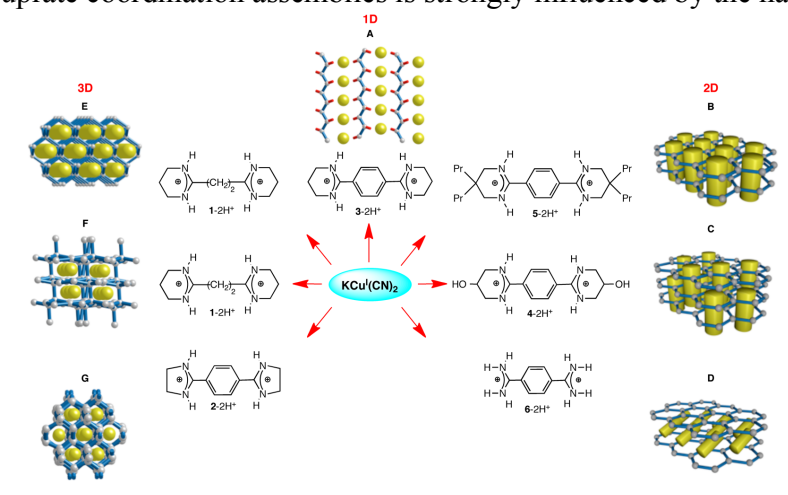

